\title{
AVERROES, TAFSÎR DEL DE ANIMA: SOBRE EL INTELECTO
}

\author{
Andrés MARTÍNEZ LORCA \\ Departamento de Filosofia. UNED
}

\author{
Al pueblo de Iraq, \\ cuna de la civilización, \\ orgullo del mundo árabe \\ y fuente de la cultura de al-Andalus, \\ hoy invadido, asesinado, expoliado \\ por los ejércitos colonialistas \\ de Estados Unidos y Gran Bretańa
}

Resumen: Averroes escribib hasta tres comentarios sobre el tratado aristotélico De Anima. El Tafsîr o Gran Comentario representa la culminación de su Psicologia y fue el texto que provocó la más viva polémica en la escolástica del siglo XIII. Desaparecido el original árabe, dependemos sólo de una traducción latina medieval, obra de Miguel Escoto. En las siguientes páginas se ofrece la primera traducción castellana integra y anotada de los principales commenta del libro III relacionados con su núcleo especulativo, el intelecto o noûs.

Abstract: Averroes wrote three Commentaries to the aristotelian treatise De Anima. The Tafsir or Long Commentary means the culmination of his Psychology and was a text that roused the most sharp controversy in XIII century Scholasticism. Having disappeared the original arabic, we rely only on a medieval latin translation made by Michael Scottus. In this paper I offer the first complete and annotated spanish translation from the main commenta of the third book connected with its theoretic crux, noûs or Intellect. 


\section{Introducción}

\section{El Tafsîr del De Anima}

Del conjunto de las obras aristotélicas Averroes prestó una atención especial al pequeño tratado Sobre el alma, hasta el punto de llegar a redactar a lo largo de su vida hasta tres comentarios. Creo que ello se debe fundamentalmente a estas dos razones: por representar ese tratado una introducción general a las obras biológicas, es decir, una síntesis preliminar de lo que llama en el Kulliyat «la Filosofía Natural», y también por ser el texto en el que Aristóteles expone más a fondo su concepción del intelecto.

Del Compendio contamos con una valiosa edición crítica del texto árabe, preparada durante largo tiempo por un prestigioso medievalista español ${ }^{1}, y$ cuya traducción representó una novedad en el panorama internacional ${ }^{2}$.

El Comentario Medio, cuyo texto árabe se conserva en caracteres hebreos, ha sido editado más recientemente por un estudioso norteamericano ${ }^{3}$. No se ha publicado hasta el momento una traducción completa de este Comentario, aunque hay dos versiones modernas (inglesa y francesa) en avanzado proceso de realización.

En cuanto al Gran Comentario o Tafîr, no se ha conservado el texto árabe. Sólo disponemos de una traducción latina medieval, obra de Miguel Escoto, en una tan meritoria como polémica edición ${ }^{4}$. En efecto, ésta representó un avance respecto a la tradición impresa de los siglos XV y XVI, pero, en su ausencia de toda referencia interna tanto a las restantes obras de Averroes como al Corpus aristotelicum, ofrece un texto latino descarnado que resulta casi enigmático para un lector moderno ${ }^{5}$.

1 Epitome De Anima, edición de S. Gómez Nogales, Madrid, CSIC/Instituto HispanoÁrabe de Cultura, 1985.

2 La Psicologia de Averroes. Comentario al libro sobre el alma de Aristoteles, traducción, introducción y notas de S. Gómez Nogales, prólogo de A. MarTfNez LORCA, Madrid, UNED, 1987.

3 Averroes' Middle Commentary on Aristotle's de Anima, edición, traducción y notas de A.L. IVRY, revisión de M. MAHDI, El Cairo, The Egyptian Academy of the Arabic Language and Supreme Council of Culture, 1994.

4 Averrois Cordubensis Commentarium Magnum in Aristotelis De anima libros, edición de F. STUART Crawford, Cambridge, Mass., The Mediaeval Academy of America, 1953. En adelante, la abreviatura $G C$ indicará este Gran Comentario en la edición de F. STUART CRAWFORD.

5 En otro lugar he estudiado a fondo los problemas hermenéuticos que plantea el texto latino de ESCOTO: "La noética de Averroes en el "Gran Comentario al Libro sobre el 
Aunque es una cuestión debatida la integración orgánica de los diversos Comentarios averroístas sobre el De Anima dentro de la evolución de su pensamiento, y en especial el lugar del Comentario Medio en dicho proceso así como la datación de la revisión o segunda edición del Compendio, existe, sin embargo, un consenso generalizado entre los estudiosos a la hora de valorar el Tafsîr o Comentario literal como la culminación de la Psicología de Averroes y su posición de madurez sobre el tema. A ello hay que añadir que este Gran Comentario fue el texto que marcó como ningún otro la polémica filosófica en la Escolástica latina y posteriormente en el pensamiento renacentista. Al volver, pues, sobre estas páginas tan decisivas en la Historia de la Filosofía, podemos trazar un cuadro más preciso de las teorías medievales sobre el intelecto y comprender mejor el por qué de los diversos puntos de vista en ellas implicados, de sus razones pero también de sus prejuicios y malentendidos.

\section{La Noética de Averroes}

Averroes comienza subrayando la diferencia esencial entre sensación e intelección. El intelecto no está mezclado con el cuerpo, es impasible y separado. Como podemos leer con frecuencia en este Gran Comentario, intellectus non est virtus in corpore, "el intelecto no es una facultad en un cuerpo». Avanzando respecto a Aristóteles, para quien el cerebro no desempeñaba ningún papel cognitivo sino que era sólo un simple refrigerador del corazón, el filósofo cordobés afirma que la imaginación, la memoria y la cogitativa residen en el cerebro. Sin embargo, continúa la tradición aristotélica al reconocer que el intelecto no tiene órgano, basándose en el argumento de que el alma humana es única en cada individuo y es ella la que unifica al cuerpo.

Más adelante, contrapone la individualidad del alma a la universalidad del intelecto. Las facultades receptivas del alma (imaginativa, rememorativa y cogitativa) están en el hombre, son materiales, y por eso no hay recuerdo tras la muerte. De ahí que Averroes distinga entre la reflexión, que es individual, generable, corruptible y procede de la cogitativa, y la intelección, que es universal en cuanto acción propia del intelecto.

En cuanto a las clases de intelecto, Averroes habla de intelecto material, intelecto habitual e intelecto agente. El primero de ellos, en cuanto 
que es potencial y receptivo, le planteó diversas aporías a las que él intentó responder del modo más coherente posible. Veamos algunas de ellas: ¿Cómo hacer compatible un intelecto sin mezcla, impasible y separado tratándose de un intelecto en potencia? ¿Y cómo puede ser uno mientras los inteligibles están multiplicados por los individuos? No procede entrar ahora en el detalle de las respuestas formuladas por Averroes, que se distinguen, en todo caso, por su finura especulativa ${ }^{6}$. Pero sí conviene señalar que su posición respecto al intelecto material no fue uniforme, sino que varió con frecuencia, como nos indican claramente los respectivos comentarios al tratado aristotélico. Todo parece indicar que ninguna de sus respuestas le pareció concluyente, dada la oscuridad del tema.Temistio, entre los comentaristas griegos, y Avempace, entre los pensadores islámicos, influyeron de modo decisivo en su propia posición, pero no hasta el punto de coincidir con ellos por completo, pues en algunos puntos centrales se alejó de ambos intentando superar lo que él consideraba contradicciones internas.

El intelecto habitual, por su parte, es producido y hace que el intelecto material pueda concebirlo todo. Este tercer intelecto, añadido por el peripatetismo árabe al esquema bipartito aristotélico, procede de Alejandro de Afrodisia. Es al que menos atención se presta de los tres en este Gran Comentario.

La concepción del intelecto agente en Averroes significa una novedad absoluta en la Edad Media. El filósofo cordobés es, en efecto, el primero que considera a este intelecto intrínseco al hombre: intellectus agens existit in anima nobis, se lee en estas páginas ${ }^{7}$. Crea los inteligibles haciéndolos pasar de la potencia al acto, y es él mismo inmaterial y eterno.

La máxima perfección posible se alcanza cuando el hombre logra la unión con el intelecto agente. Es la culminación del proceso intelectivo y, en última instancia, la divinización por el intelecto.

alma de Aristóteles», en La Ciudad de Dios, Real Monasterio de El Escorial, CCXV, 2002, pp. 823-834.

6 Una sintesis de ellas puede verse en mi artículo antes citado, pp. 863-870.

$7 G C$, III, 5, p. 390. El número romano indica el libro, y el siguiente número arábigo, la numeración del texto aristotélico comentado, es decir, del respectivo commentum; la referencia de página señala, evidentemente, la edición crítica latina de CRAWFORD. 


\section{Nuestra traducción}

No existe hasta ahora traducción castellana del Gran Comentario al Libro sobre el Alma de Aristóteles ${ }^{8}$. Por otra parte, las dos Antologías de textos de Averroes publicadas en España con motivo del VIII Centenario de su muerte, tampoco incluyen en su selección ninguna página del Tafsîr del De Anima. En la primera de ellas ${ }^{9}$, el contenido es muy ambicioso y refleja bien la gran variedad de materias filosóficas y científicas que trató el pensador cordobés a lo largo de su fecunda vida intelectual ${ }^{10}$. De tema psicológico se reproducen algunos parágrafos extraídos de la traducción de S. Gómez Nogales del Epitome De Anima ${ }^{11}$, al que ya aludí antes. En tres ocasiones se utilizan como texto-base traducciones medievales del árabe: en dos de ellas, existe el texto árabe aunque se ha preferido usar la traducción latina como fuente ${ }^{12}$; y en una tercera, sólo disponemos de una versión hebrea, al haber desaparecido el original árabe ${ }^{13}$. La segunda Antología es de marcada orientación escolar y, por tanto, más limitada en sus pretensiones ${ }^{14}$. También aquí echamos en falta el Tafsîr del De Anima o Gran Comentario: sólo se reproducen algo más de dos páginas de su comentario más breve sobre el tema, el Compendio Sobre el alma ${ }^{15}$.

Por tanto, la primera finalidad de nuestro trabajo consiste en cubrir esta laguna, a todas luces injustificable dada la centralidad del texto en la filosofía

8 Únicamente he podido localizar la versión de algunas páginas de este Comentario, carentes de cualquier anotación doctrinal, y, por consiguiente, casi herméticas para la mayoría de los lectores, en la antología de Clemente FERNANDEZ, Los filósofos medievales. Selección de textos, Madrid, BAC, 1980, tomo I, pp. 711-725.

9 Antologia de Averroes, introducción y selección de Miguel CRUz Hernandez, Sevilla, Fundación El Monte, 1998.

10 El conjunto de las traducciones de textos ocupa las pp. 67-334.

11 Texto XVI [De Anima], pp. 157-180.

12 Textos XX y XXI [Colliget], traducción de Esteban ToRRE, pp. 244-268. Esta importante obra médica podemos manejarla ya en una valiosa traducción directa del árabe llevada cabo por dos conocidos investigadores espanoles, que constituye la primera traducción del Kulliyyât a un idioma moderno: Averroes, Libro de las generalidades de la medicina [Kitab alKulliyyât fil-tibb], introducción, traducción castellana e indices de M.* Concepción VAzQUEZ DE BENITO y Camilo Álvarez DE MORAles, Madrid, Editorial Trotta, 2003.

13 Texto XIX [Exposición de la "República" de Platón], traducción de M. Cruz HERNANDEZ, pp. 195-243.

14 Josep PUIG MONTADA, Averroes, juez, médico y filosofo andalusi, Sevilla, Consejería de Educación y Ciencia de la Junta de Andalucía, 1998. La Antología de textos propiamente dicha comprende las pp. 73-119.

is Texto 12, pp. 106-108. 
medieval. En las siguientes páginas ofrecemos al lector, en su integridad, los principales commenta del libro III relacionados con el núcleo teórico de esta obra, el intelecto. He aprovechado la excelente traducción francesa de Alain de Libera, ampliamente anotada ${ }^{16}$. También me ha sido útil la versión italiana ${ }^{17}$.

En mi traducción he procurado ser lo más fiel posible al texto latino ofrecido por Escoto, cuyos términos y expresiones más característicos reproduzco con frecuencia. Mis notas de tipo filosófico intentan iluminar el oscuro léxico latino mediante una interpretación coherente y no forzada del pensamiento de Averroes, sobre el telón de fondo de la Psicología aristotélica tal y como se expone en el De Anima. Los estudiosos de filosofía medieval y los admiradores del gran sabio andalusí, cada día más numerosos, por fortuna, encontrarán en estas páginas, según espero, alicientes para seguir avanzando en el conocimiento de nuestros clásicos.

\section{Traducción}

Averroes, Gran comentario al libro sobre el alma de Aristóteles

\section{Libro Tercero}

Texto 1. Sobre la parte del alma por la cual ella conoce y piensa (si es diferente o no es diferente en magnitud, pero sí en la noción) hay que indagar sobre cuál es su diferencia, y cómo es concebir por el intelecto.

De parte autem anime per quam anima cognoscit et intelligit (utrum est differens aut non differens in magnitudine, sed in intentione) perscrutandum est de differentia que sit, et quomodo sit formare per intellectum: De Anima, 429 a10-13.

Una vez terminada la explicación sobre la facultad imaginativa, cuál sea y por qué, comienza [Aristóteles] a indagar sobre la facultad racional y a preguntar

16 Averroès, Lintelligence et la pensée. Sur le De anima, presentación y traducción de Alain De LiberA, París, GF Flammarion, $1998,2 .^{2}$ ed.

17 Averroe e l'intelletto pubblico. Antologia di scritti di lbn Rushd sull'anima, edición e introducción de A. Illuminat, traducción de L. ForTINI, Roma, Manifestolibri, 1996. 
en qué se diferencia de la facultad sensitiva e imaginativa ${ }^{18}$, tanto en la primera como en la última perfección, en la acción y en la afección propia, al ser necesario que las facultades diferentes se distingan en estas dos cosas. Y puesto que su propósito es ese, comienza primero a demostrar que el ser de esta facultad, es decir, el que ella sea diferente de las otras facultades ${ }^{19}$ del alma es evidente por sí, puesto que por esta facultad se diferencia el hombre de los otros animales, como se ha dicho en muchos textos. $\mathrm{Y}$ esto que es dudoso, si se distingue de las otras facultades por el sujeto y por la noción, o si sólo se distingue por la noción, no es necesario saberlo de antemano en esta investigación, sino que a partir de esta investigación se manifestará cómo es. (...) Y lo primero es indagar cómo concebir por el intelecto ${ }^{20}$, si es una acción o recepción; pues conocer las acciones del alma es anterior en nosotros a conocer su sustancia. Y parece que entendía aquí por conocer ${ }^{21}$ el conocimiento teórico ${ }^{22}$, y por pensar ${ }^{23}$, el conocimiento práctico ${ }^{24}$, al ser el intelecto común a todos, pero no el conocimiento.

Texto 2. Digamos, pues, que si concebir por el intelecto es como sentir, será afectado de algún modo por el inteligible, o algo semejante.

Dicamus igitur quod, si formare per intellectum est sicut sentire, aut patietur quoquo modo ab intellecto, aut alid simile: 429 a 13-15.

Se plantea [Aristóteles] si la operación intelectiva ${ }^{25}$ es una potencia pasiva, como los sentidos, o si es activa; y si es pasiva, si ello sucede porque es material de alguna manera y mezclada con el cuerpo; o si de ningún modo es pasiva, porque no es material ni está mezclada con un cuerpo. Digamos, pues, que si la operación intelectiva fuera como la sensación ${ }^{26}$, es decir, una poten-

18 Virtute sensus et ymaginationis.

19 Virtutes, "facultades", traduce el sustantivo griego dynámeis.

20 Formare per intellectum equivale al verbo griego noeîn, y puede traducirse también por "representar o formar por el intelecto".

${ }_{21}$ Cognoscere, que traduce el verbo griego gignóskein.

22 Cognitionem speculativam.

23 Intelligere, que vierte el verbo phroneîn. La phrónesis aristotélica es la prudentia de los latinos, es decir, una sabiduría práctica, un saber para la acción. Muy acertadamente Guillermo de Moerbeke tradujo ese verbo griego, en el Comentario al De Anima de Juan FILOPON, por prudentiare.

24 Cognitionem operativam.

25 Traduzco así la expresión formare per intelectum.

26 Sentire. 
cia pasiva, de modo que la potencia intelectiva primera ${ }^{27}$ reciba los inteligibles y los aprehenda de la misma manera que la potencia sensitiva recibe los sensibles y los aprehende, entonces necesariamente ocurrirá una de dos: o que le sobrevenga por el inteligible algún cambio y afección ${ }^{28}$ semejante al cambio que le sobreviene al sentido por el sensible, ya que la perfección del sentido es una potencia en el cuerpo, o bien que no le suceda ningún cambio semejante al cambio de los sentidos y a la afección en ellos producida por el sensible, ya que la perfección primera del intelecto no es una potencia en el cuerpo ${ }^{29}$.

Texto 3. Por consiguiente, es necesario que no sea pasivo, sino que reciba la forma y sea en potencia como aquello, sin serlo. Y su estructura será según esta semejanza: como la facultad sensitiva respecto a los sensibles, así el intelecto respecto a los inteligibles.

Oportet igitur ut non sit passivum, sed recipit formam, et est in potentia sicut illud, non illud. Et erit dispositio eius secundum similititudinem: sicut sentiens apud sensibilia, sic intellectus apud intelligibilia: 429 a $15-18$.

(...) $\mathrm{El}$ intelecto es en cierto modo una potencia pasiva, y es algo que no experimenta cambio, porque ni es cuerpo, ni una potencia en un cuerpo.

Si se investiga esto a fondo, se descubrirá que necesariamente esta parte del alma ${ }^{30}$ por la cual se realiza la operación intelectiva es una potencia no sujeta a cambio por la forma que aprehende, y que de la noción de receptividad ${ }^{31}$ sólo tiene el que recibe la forma que aprehende, y porque es en potencia aquello que aprehende, como la facultad sensitiva, pero no porque sea algo concreto en acto, bien un cuerpo, bien una potencia en un cuerpo, como le sucede a la sensación.

27 Prima virtus intellectiva: Averroes se refiere al intelecto material receptor, del que hablará más adelante.

28 Transmutatio et passio. Transmutatio traduce el término griego metabolé, cambio; passio traduce el término páthos, afección o pasión.

29 Non est virtus in corpore.

30 Ista pars anime. Hay que llamar la atención sobre esta expresión de Averroes porque con ella se explica claramente que aquí no se habla de almas, sino de potencias o facultades del alma. Esto mismo volverá a subrayarlo más adelante a propósito de las diversas clases de intelecto.

31 De intentione passionis. 
(...) Y puede interpretarse [así el ejemplo anterior]: y su estructura será de este tipo: como la facultad sensitiva respecto a los sensibles, así el intelecto respecto a los inteligibles, o sea, que afirmar que el intelecto no es pasivo, no contradice el que la relación de él respecto al inteligible sea como la de la sensación respecto a lo sensible, sino que el conceder que posee esta analogía implica necesariamente que no está sujeto a cambio. Y nos fuerza a tal interpretación el que sea evidente por sí, o casi, que el intelecto tiene esta relación, y que ello representa como un principio para saber que ni es pasivo, ni está sujeto a cambio.

Texto 4. Es necesario, pues, si piensa todas las cosas, que sea no mezclado, como dice Anaxágoras, para que mande, o sea, para que conozca. Porque si en él apareciera algo, lo que aparezca impedirá lo extraño, ya que es otra cosa.

Oportet igitur, si intelligit omnia, ut sit non mixtum, sicut dixit Anaxagoras, ut imperet, scilicet ut cognoscat. Si enim in eo apparuerit, apparens impediet alienum, quia es aliud: 429 a 18-20.

Tras haber afirmado [Aristóteles] que el intelecto material receptor ${ }^{32}$ debe pertenecer al género de las potencias pasivas, y que a pesar de esto no experimenta cambio en la recepción [del inteligible], porque ni es un cuerpo, ni una potencia en el cuerpo, ofrece una demostración de ello.

Es necesario que si el intelecto aprehende ${ }^{33}$ todo lo que existe fuera del alma, sea considerado en este aspecto, antes de la aprehensión, dentro del género de las potencias pasivas y no de las activas, y que no esté mezclado con los cuerpos, es decir, que ni sea cuerpo, ni una potencia natural o animal en un cuerpo, como dice Anaxágoras.

$\mathrm{Y}$ es necesario que no esté mezclado, para que aprehenda todas las cosas y las reciba. Pues si estuviera mezclado, entonces sería un cuerpo o una potencia en un cuerpo y si fuera una de estas [dos cosas], tendría una forma propia, la cual le impediría recibir una forma ajena.

32 Este paso está dedicado al intelecto material y constituye un intento de definirlo con precisión. La amplitud del comentario de Averroes a las dos líneas del texto aristotélico, indica la importancia que le concede al tema.

33 Comprehendit, verbo que traduce el griego orân: aprehender, percibir, captar. 
Hay que reflexionar ahora sobre estas proposiciones en las que Aristóteles manifiesta estas dos conclusiones sobre el intelecto: que pertenece al género de las potencias pasivas, y que no está sujeto a cambio, porque ni es un cuerpo, ni una potencia en un cuerpo. Estas dos [conclusiones] son el fundamento de todo lo que se diga sobre el intelecto.

Digamos, por tanto, que formar por el intelecto se incluye en cierto modo entre las potencias receptivas ${ }^{34}$, como la facultad sensitiva. Las potencias pasivas tienen movimiento por aquello a lo cual se refieren; mientras que las activas mueven aquello con lo cual se relacionan. $Y$ como una cosa no mueve sino en cuanto que está en acto, y es movida en cuanto que está en potencia, es necesario que, en cuanto que las formas de las cosas están en acto fuera del alma, muevan al alma racional en cuanto las aprehende, de modo semejante a los sensibles que, en tanto son entes en acto, mueven necesariamente a los sentidos y los sentidos son movidos por ellos. Y por esto el alma racional necesita considerar las entidades ${ }^{35}$ que están en la facultad imaginativa, lo mismo que el sentido necesita mirar los sensibles. Pero como parece que las formas de las cosas externas mueven esta facultad [racional] tan pronto como la mente las aparta de la materia, $y$ las hace en primer lugar inteligibles en acto después de haber sido inteligibles en potencia, parece de ese modo que este alma es activa y no [sólo] pasiva. Pues en cuanto que los inteligibles la mueven, es pasiva; y en cuanto que son movidos por ella, es activa. Y por esto afirma Aristóteles después que es necesario poner en el alma racional estas dos diferencias, a saber, la potencia de la acción ${ }^{36}$ y la potencia de la pasión o afección ${ }^{37}$. $Y$ dice claramente que ninguna de ambas partes de ella es generable, ni corruptible. (...)

Por qué la sustancia que recibe estas formas necesariamente no es un cuerpo, ni una potencia en un cuerpo, resulta evidente de las proposiciones que formula Aristóteles en esta explicación. La primera es que esta sustancia recibe todas las formas materiales; y ello es sabido respecto a este intelecto [material]. La segunda es que todo lo que recibe algo, es necesario que esté

${ }^{34}$ Est de virtutibus receptivis. Averroes comienza a introducir aquí una interesante distinción entre pasividad y receptividad.

35 Intentiones. Prefiero aquí la referencia al término árabe ma’ nâ que emplea Averroes en otras obras, en lugar del más ambiguo término de «intenciones", que remite al nombre latino utilizado por el traductor, de tantas resonancias escolásticas.

36 Virtutem actionis.

37 Virtutem passionis. 
despojado ${ }^{38}$ de la naturaleza de lo recibido, y que su sustancia no sea específicamente la sustancia de lo recibido. Pues si lo que recibe fuera de la naturaleza de lo recibido, entonces una cosa se recibiría a sí misma, y también un motor sería movido. Por ello es necesario que el sentido que recibe el color carezca de color, y que el que recibe el sonido, carezca de sonido; esta proposición es necesaria y no ofrece duda. De estas dos [proposiciones] se sigue que esta sustancia que llamamos intelecto material no tiene en su naturaleza ninguna de estas formas materiales. Y puesto que las formas materiales o son cuerpos o formas en un cuerpo, es evidente que esta sustancia que llamamos intelecto material ni es un cuerpo, ni una forma en un cuerpo; por consiguiente, [el intelecto material] no está mezclado en absoluto con la materia.

Debes saber que esto se deduce necesariamente porque es una sustancia, y que el que recibe las formas de las cosas materiales o las formas materiales no tiene en sí forma material, es decir, compuesta de materia y forma. No es tampoco una forma de las formas materiales;pues las formas materiales no son separables. Ni tampoco pertenece a las formas primeras simples, ya que éstas son separables ${ }^{39}(.$.$) Es, pues, [el intelecto material] un ente distinto de la$ forma ${ }^{40}$, de la materia ${ }^{41}$ y de su compuesto ${ }^{42}$.

Pero si esta sustancia tiene una forma propia, distinta ontológicamente ${ }^{43} \mathrm{de}$ las formas materiales, todavía no resulta manifiesto de esta explicación. Pues la proposición que afirma que el que recibe debe estar despojado de la naturaleza de lo recibido, se entiende de la naturaleza de la especie de lo recibido, no de la naturaleza de su género, y de lo alejado en extremo, ni sobre todo de lo que se dice por homonimia ${ }^{44}$. Y por esto dijimos que en el sentido del tacto se encuentra un punto medio entre los contrarios que percibe; los contrarios, en efecto, son distintos específicamente de los puntos intermedios. $\mathrm{Y}$ al ser así la estructura del intelecto material, a saber, que es un ente, que es una potencia separada ${ }^{45}$, y que no tiene forma material, es evidente que él no es pasivo, pues lo pasivo, es

\footnotetext{
38 Sit denudatum.

39 Laguna en la tradución latina.

40 Porque el intelecto material está en potencia, a diferencia de la forma.

41 Porque el intelecto material recibe los inteligibles en acto, no en potencia como la materia.

42 Porque el intelecto material no es una sustancia compuesta.

43 In esse.

44 Per equivocationem.

45 Potentia abstracta.
} 
decir, sujeto a cambio, es como las formas materiales, y que es simple, como afirma Aristóteles, y separable. Y de este modo se entiende la naturaleza del intelecto material en Aristóteles; más adelante hablaremos de sus dudas.

Texto 5. Y así no tendrá sino esta naturaleza, es decir, que es posible. Pues aquello del alma que se llama intelecto (y llamo intelecto a aquello por lo cual distinguimos y razonamos) no es en acto ninguno de los entes antes de pensar.

Et sic non habebit naturam nisi istam, scilicet quod est possibilis. Illud igitur de anima quod dicitur intellectus (et dico intellectum illud per quod distinguimus et cogitamus) non est in actu aliquod entium antequam intelligat: 429 a 21-24.

Tras haber manifestado que el intelecto material no tiene una forma material, comienza a definirlo y dice que, en este respecto, no tiene sino una naturaleza de posibilidad para recibir las formas inteligibles materiales ${ }^{46}$. Aquello del alma que llamamos intelecto material no tiene otra naturaleza y esencia ${ }^{47}$ por la cual se constituya en cuanto que es material, sino la naturaleza de la posibilidad, al estar despojado de todas las formas materiales e inteligibles.

[Aristóteles] entiende aquí por intelecto la facultad del alma que se llama intelecto en sentido estricto ${ }^{48}$, y no la facultad que se llama intelecto en sentido amplio ${ }^{49}$, o sea, lo que se llama en lengua griega la facultad imaginativa ${ }^{50}$, sino la facultad por la cual distinguimos las cosas especulativas y deliberamos ${ }^{51}$ sobre las acciones futuras.

Definición de intelecto material: aquello que es en potencia todas las intenciones de las formas materiales universales, y no es en acto ninguno de los entes antes de concebirlos. El intelecto material se distingue de la materia prima en que es en potencia todas las intenciones de las formas universales materiales, mientras que la materia prima es en potencia todas las formas sensibles indivi-

46 Llama la atención la extraordinaria extensión de este commentum, con un total de 752 líneas en 27 páginas de la edición crítica latina, dedicado fundamentalmente al estudio del intelecto material.

47 Naturam et essentiam.

48 Vere.

49 Large.

50 Es decir, la phantasía.

51 Cogicamus. 
duales, sin conocerlas ni aprehenderlas. La causa por la cual esta naturaleza ${ }^{52}$ distingue y conoce, mientras que la materia prima no conoce ni distingue, es porque la materia prima recibe formas diferenciadas, es decir, individuales y singulares; esta [naturaleza], sin embargo, recibe formas universales. Y de esto se sigue que esta naturaleza no es algo concreto, ni un cuerpo, ni una potencia en un cuerpo; pues si así fuera, entonces recibiría las formas en cuanto son diferenciadas y singulares, y en tal caso, las formas existentes en ella serían inteligibles en potencia ${ }^{53}$, y así no distinguiría ella la naturaleza de las formas en cuanto que son formas, como ocurre en las formas individuales, bien sean espirituales ${ }^{54} \mathrm{o}$ corporales. (...) Y por esto no es necesario que [el intelecto] pertenezca al género de las materias singulares en las que está incluida una forma, ni [sea como] la misma materia prima. Puesto que si así fuera, entonces la recepción en ellos sería del mismo género; sin embargo, la diferencia en la naturaleza de lo recibido produce la diferencia en la naturaleza del receptor. Esto fue lo que llevó a Aristóteles a establecer esta naturaleza que es distinta de la naturaleza de la materia, de la naturaleza de la forma y de la naturaleza del compuesto [hilemórfico].

$\mathrm{Y}$ esto indujo a Teofrasto, Temistio y a muchos comentadores a creer que el intelecto material es una sustancia ingenerable e incorruptible... y a opinar que tal era la enseñanza de Aristóteles. Que este intelecto es así, se muestra claramente a quien tenga presente la demostración de Aristóteles y sus palabras; en cuanto a la demostración, según lo que expusimos; y en cuanto a sus palabras, porque afirmó que [el intelecto material] no es pasivo, es separable y simple. Estos tres términos son usados respecto de él por Aristóteles, y no es correcto, más aun es absurdo ${ }^{55}$, referirlos a lo generable y corruptible en una argumentación demostrativa.

Pero cuando vieron después que Aristóteles decía que necesariamente si hay un intelecto en potencia ${ }^{56}$, también habrá un intelecto en acto ${ }^{57}$, a saber, [el

52 El intelecto material.

53 Como sucede en la mareria prima, según veíamos antes.

54 Spiritualis, ruhâniyya: el término procede de Avempace, con quien parece polemizar. Este distingue en El régimen del solitario, introducción, traducción y notas de J. LOMBA, Madrid, Trotta, 1997, p. 111 y ss., las formas del primer nivel espiritual y las del segundo nivel espiritual (que son las superiores y corresponden al intelecto, humano y agente).

${ }_{55}$ Remotum [a ratione], desatinado, alejado de la verdad, incoherente; vierte el adjetivo griego álogon.

56 Intellectus in potentia.

57 Intellectus in actu. 
intelecto] agente ${ }^{58}$ (que es aquél que pasa de la potencia al acto aquello que está en potencia), y que habría un intelecto sacado de la potencia al acto (y es aquél al que el intelecto agente pone en el intelecto material, del mismo modo que el arte pone las formas artísticas en la materia del artesano), opinaron entonces que este tercer intelecto, que el intelecto agente pone en el intelecto material receptor (y que es el intelecto especulativo ${ }^{59}$ ), necesariamente es eterno; en efecto, al ser eterno el receptor y al serlo también el agente, es menester que lo producido [por ambos] sea necesariamente eterno. Al opinar esto, se deduce que en realidad no exista intelecto agente, ni [intelecto] producido, pues uno y otro no se explican sino con la generación en el tiempo. O se dice que llamar a uno agente y a otro producido ${ }^{60}$ es sólo por semejanza, y que el intelecto especulativo no es sino la perfección ${ }^{61}$ del intelecto material por medio del intelecto agente, de tal modo que el [intelecto] especulativo sea algo compuesto del intelecto material y del intelecto que está en acto. Y que el intelecto agente a veces piensa cuando está unido a nosotros ${ }^{62}$ y a veces no piensa, le sucede por la mezcla, es decir, por la mezcla de él con el intelecto material. Sólo por esto Aristóteles se vio obligado a introducir un intelecto material, y no porque los inteligibles especulativos sean generables y producidos.

Confirmaron esto por lo que manifestó Aristóteles, que el intelecto agente existe en nuestra alma ${ }^{63}$, pues parece que despojamos en primer lugar las formas de la materia, y después las concebimos. Y despojarlas ${ }^{64}$ no es sino hacerlas inteligibles en acto después que lo eran en potencia, del mismo modo que aprehenderlas ${ }^{65}$ no es sino recibirlas.

Cuando vieron que esta acción que consiste en crear los inteligibles y generarlos dependía de nuestra voluntad y que aumentaba en nosotros según el incremento del intelecto que está en nosotros, o sea, del [intelecto] especulativo,

58 [Intellectus] agens.

59 Intellectus speculativus, intelecto especulativo o teorético: noûs theoretikós en terminología de Temistio. Equivale al «intelecto habitual" introducido por Alejandro DE AFRODISIA.

60 Factum: el intelecto producido, es decir, el “intelecto habitual” en terminología de Alejandro.

61 Perfectio, es decir, la entelékheia aristotélica.

62 Copulatus nobis.

63 Intellectus agens existit in anima nobis.

64 Denudare eas.

65 Comprehendere eas. 
y ya se explicó que el intelecto que crea y genera los inteligibles y las cosas inteligidas ${ }^{66}$ es la inteligencia agente ${ }^{67}$, por eso dijeron que el intelecto que está en hábito es este intelecto, pero que a veces disminuye y a veces aumenta a causa de la mezcla. Ello, pues, llevó a Teofrasto, Temistio y otros a opinar esto sobre el intelecto especulativo y a decir que tal era la opinión de Aristóteles.

Y sobre esto surgen no pocos problemas ${ }^{68}$. Primer problema ${ }^{69}$ : tal posición contradice a Aristóteles para quien la relación ${ }^{70}$ del inteligible en acto con el intelecto material es como la relación de lo sensible con la facultad sensitiva. Y contradice a la verdad en sí. Pues si concebir por el intelecto fuera eterno, también sería eterno lo concebido por el intelecto, por lo cual sería necesario que las formas sensibles fueran inteligibles en acto fuera del alma, y absolutamente inmateriales; y esto se opone a lo que encontramos en estas formas.

Y también Aristóteles dice abiertamente en este libro que la relación de la facultad racional distintiva con las intenciones de las formas imaginadas es como la relación de los sentidos con los sensibles; por esto, el alma nada piensa sin la imaginación ${ }^{71}$, del mismo modo que los sentidos nada perciben sin la presencia de lo sensible. Si pues las intenciones que el intelecto capta de las formas imaginadas fueran eternas, entonces las intenciones de las facultades imaginativas serían eternas. Y si éstas fueran eternas, entonces las sensaciones serían eternas; las sensaciones, en efecto, son respecto a esta facultad [imaginativa] como las intenciones imaginables respecto de la facultad racional. Y si las sensaciones fueran eternas, entonces los sensibles serían eternos, o bien las sensaciones serían intenciones distintas de las intenciones de las cosas existentes fuera del alma en la materia. Pues es imposible mantener que las mismas intenciones unas veces son eternas y otras son corruptibles, salvo que fuera posible que la naturaleza corruptible se transformara y se hiciera eterna. Es necesario,

66 Intelligibilia et intellecta. Intellecta, plural neutro, traduce el término árabe ma'qûlat, "cosas inteligidas": véase L. MASSIGNON, "Notes sur le texte original arabe du De Intellectu d'alFarabin, en E. GILSON, Les sources greco-arabes de l'augustinisme avicennisant, París, Vrin-Reprise, 1986, p. 155. En general, pueden considerarse sinónimos ambos términos, intelligibilia/intellecta, en el texto de Averroes, y vierten el término aristotélico tà noêtá.

67 Intelligentia agens.

68 Desde esta línea 117 hasta la 298 del texto latino Averroes plantea diversas aporías a los comentadores griegos de Aristóteles.

69 Questio.

70 Proportio.

71 Anima nichil intelligit sine ymaginatione. 
por tanto, si estas intenciones que están en el alma pertenecen a las cosas generables y corruptibles, que ellas también sean generables y corruptibles. Esta cuestión la he tratado a fondo en otro lugar ${ }^{72}$.

Éste es, pues, uno de los imposibles que parecen contradecir tal opinión, es decir, la ya expuesta y según la cual el intelecto material es una facultad no engendrada. Se considera, en efecto, imposible imaginar cómo los inteligibles serán producidos y esta [facultad] no lo será; pues cuando el agente es eterno y el paciente es eterno, es necesario que lo producido sea también eterno. Y si defendemos que lo producido es engendrado ( $y$ es el intelecto que está en hábito), ¿ cómo podemos decir que genera y crea los inteligibles?

Hay una segunda dificultad mucho más difícil. $Y$ es que si el intelecto material es la perfección primera del hombre, como se afirmó en la definición de alma ${ }^{73}$, y el intelecto especulativo es la perfección última, y el hombre es generable y corruptible y uno en número por la perfección última de su intelecto, es necesario que sea así [generable y corruptible] por su perfección primera, es decir, que por la perfección primera referida a los inteligibles yo sea distinto de ti, y tú distinto de mí (pues si no, tú serías por mi ser, y yo por tu ser, y el hombre [considerado] universalmente sería un ente antes de existir, y de ese modo el hombre no sería generable y corruptible en tanto que hombre, sino, de serlo, en tanto que es animal). Se considera, pues, necesario que si la perfección primera es algo concreto y numerable ${ }^{74}$ por la numeración de los individuos, ocurra del mismo modo respecto de la perfección última, y al contrario, es decir, que si la perfección última es numerada ${ }^{75}$ por la numeración de los hombres individuales, que ocurra del mismo modo respecto de la perfección primera.

Muchas otras contradicciones ${ }^{76}$ se le presentan a esta tesis. Pues si la perfección primera fuera la misma para todos los hombres, y no numerada según el número de ellos, ocurriría que, cuando yo lograra algún inteligible, tú tam-

72 Al no aludir a un paso posterior de este mismo comentario, ya que habla en tiempo pasado, podría referirse a otro comentario u opúsculo de tema psicológico. Desconozco exactamente a cuál.

73 El alma, psykhé "es la perfección, entelékheia, primera de un cuerpo natural orgánico", 412 b5-6. Aunque Aristóteles ofrece tres definiciones, ésta se suele considerar la principal. «Anima est actus corporis physici organici», repitieron los escolásticos.

74 Numerabilis.

75 Numerata.

76 Impossibilia, absurdo, contradictorio, imposible lógicamente. 
bién lo lograrías, y cuando yo olvidara algún inteligible, tú también lo olvidarías. Y otras muchas contradicciones se le presentan a tal tesis. Parece, pues, que no hay ninguna diferencia entre una y otra posición ${ }^{77}$ en cuanto a los absurdos que se derivan, o sea, de que afirmemos que son del mismo modo la perfección última y la primera, y que [una y otra] no son numeradas por la numeración de los individuos.

Para huir de todas estas contradicciones, tendríamos que afirmar que la perfección primera es esta intención, individual en la materia y numerada por la numeración de los individuos humanos, generable y corruptible. Y ya se manifestó, desde la citada demostración de Aristóteles, que no es algo determinado, ni cuerpo, ni facultad en un cuerpo. ¿Cómo, pues, podemos escapar de este error, o cuál es el camino para resolver esta dificultad?

Alejandro [de Afrodisia], por su parte, se apoya en este último razonamiento y dice que es el que mejor se adapta a los principios naturalistas, es decir, el razonamiento que concluye que el intelecto material es una facultad engendrada, de modo que lo consideramos como las restantes facultades del alma: disposiciones producidas per se en el cuerpo por la mezcla y composición ${ }^{78}$. Dice que esto no es inconcebible, a saber, que de la mezcla de elementos surja un ser tan noble y admirable, aunque esté alejado de la sustancia de los elementos por la mezcla máxima.

Y prueba que esto es posible porque la composición que primeramente se produce en los elementos, la composición de las cuatro cualidades simples, aún siendo pequeña es causa de la máxima diversidad, en cuanto que una cosa es el fuego y otra el aire.

Siendo así, no es absurdo que, por las múltiples composiciones que se dan en el hombre y en los animales, se produzcan facultades tan considerablemente diferentes de las sustancias de los elementos.

Esto lo expuso clara y universalmente al comienzo de su libro Sobre el alma ${ }^{79}$, advirtiendo que quien estudie el alma, primero debe saber de ante-

77 Es decir, las tesis expuestas respectivamente en el primero y segundo párrafo del paso anterior, líneas 158-175.

78 A mixtione et complexione.

79 Hay edición del texto griego: De anima Liber cum Mantissa, I. BRUNS, ed., Berlín, CAG, 1887. Para Alejandro, ibid., pp. 25 y 26, el alma es una facultad engendrada a partir de la mezcla de algunos elementos, pero no una mezcla ella misma. 
mano lo maravilloso de la composición del cuerpo humano. $\mathrm{Y}$ afirma también en el tratado que escribió Sobre el Intelecto según la opinión de Aristóteles ${ }^{80}$ que el intelecto material es una facultad producida por composición. Estas son sus palabras:

"Cuando de este cuerpo, al mezclarse por alguna mezcla, se genera algo de la totalidad de lo mezclado, de tal modo que sea apto para servir de instrumento de este intelecto que está en lo mezclado, y como existe en todo cuerpo y este instrumento es también un cuerpo, entonces se le llamará intelecto en potencia; y es una facultad producida por la mezcla que tiene lugar en los cuerpos, preparada para recibir al intelecto que está en acto».

Pero esta opinión sobre la sustancia del intelecto material se aleja al máximo de las palabras de Aristóteles y de su demostración; de las palabras, donde dice que el intelecto material es separable, que no tiene órgano corporal, y que es simple y no sufre, o sea, que no experimenta cambio, y donde elogia a Anaxágoras por haber afirmado que no está mezclado con el cuerpo; y de su demostración, como es sabido por lo que hemos escrito.

Alejandro expone la demostración de Aristóteles de la cual concluye que el intelecto material no es pasivo, ni algo determinado ${ }^{81}$, ni cuerpo, ni facultad en un cuerpo, refiriéndose así a la preparación misma y no al sustrato de la preparación. Y por esto dice en su libro Sobre el alma que el intelecto material se asemeja más a la preparación que hay en una tablilla no escrita que a la tablilla preparada; y que de esta preparación se puede decir en verdad que no es algo determinado, ni cuerpo, ni facultad en un cuerpo, y que no es pasiva.

Pero esto que afirma Alejandro no vale nada ${ }^{82}$. Pues esto se afirma en verdad de toda preparación, a saber, que ni es cuerpo, ni forma singular en un cuerpo. ¿ Y por qué lo asignó Aristóteles a la preparación que está en el intelecto entre otras, si no pretendía demostrarnos la sustancia del preparado sino la sustancia de la preparación? Mas es imposible decir que la preparación sea

80 De este tratado hay edición árabe de A. BADAwI y latina de G. Théry, De intellectu et intellecto.

81 Literalmente neque aliquid hoc.

82 La expresión de Averroes es contundente: Sed hoc quod dixit Alexander nichil est. Sin embargo, en el tratado De animae beatitudine, donde se alude a la misma cuestión, el juicio es más matizado y se sugiere que la interpretación alejandrina hunde sus raíces en el texto aristotélico. 
una sustancia, cuando esto a lo que llamamos sustrato de esta preparación no es un cuerpo, ni una facultad en un cuerpo. En lo que concluyó la demostración de Aristóteles es en una entidad distinta de aquella según la cual se afirma que la preparación no es un cuerpo, ni facultad en un cuerpo.

Y esto resulta evidente de la demostración de Aristóteles. Pues la proposición según la cual en todo lo que recibe algo es necesario que no exista en acto alguna cosa de la naturaleza de lo recibido, es evidente porque la sustancia del preparado y su naturaleza buscan tener este predicado según el cual es preparado. La preparación, en efecto, no es el receptor pero el ser de la preparación por el receptor es como [el ser] del accidente propio. Por esto, cuando hay recepción, no hay preparación y permanecerá el receptor; y de la demostración de Aristóteles resulta evidente para todos los comentadores que tal es el intelecto ${ }^{83}$.

Que algo no sea un cuerpo, ni una facultad en un cuerpo, se dice de cuatro modos diversos. El primero de ellos es el sujeto de los inteligibles ${ }^{84}$, y es el intelecto material cuyo ser se ha demostrado en qué consiste. El segundo es la preparación misma que existe en las materias, y está próximo al modo según el cual se dice que la privación en general no es un cuerpo ni facultad en un cuerpo. El tercero es la materia prima, cuyo ser también se ha demostrado. Y el cuarto es las formas separadas ${ }^{85}$, cuyo ser se ha demostrado asimismo. Y todos estos modos son diversos.

El querer huir de las dificultades mencionadas, llevó a Alejandro a esta exposición incoherente de un error manifiesto. Vemos también que Alejandro se apoya en que la perfección primera del intelecto debe ser una facultad engendrada sobre las proposiciones generales contenidas en la definición de alma, es decir, porque es la perfección primera de un cuerpo natural orgáni$\mathrm{co}^{86}$. Y afirma que esta definición es verdadera respecto de todas las partes del alma con la misma intención. Da razón de esto: decir que todas las partes del alma son formas es unívoco, o casi, y puesto que la forma, en tanto que es fin

83 Leo et intellectus, siguiendo el manuscrito D.

84 Subiectum intellectorum.

85 Forme abstracte.

86 Prima perfectio corporis naturalis organici, 412b 5-6. De acuerdo con la indicación de Aristóteles, suele considerarse la principal de las tres definiciones de psykhé o alma que él mismo ofrece en el tratado. La traducción de entelékheia por perfectio, como hace Escoto, es excelente; en los autores escolásticos es frecuente, sin embargo, el uso del término actus en lugar de perfectio. 
de lo que tiene forma, es imposible que esté separada, es necesario, dado que las perfecciones primeras del alma son formas, que no estén separadas. Y por esto invalida que en las perfecciones primeras del alma exista una perfección separada, como se dice del piloto respecto de la nave, o bien universalmente habrá en ella alguna parte que es llamada perfección con intención distinta de aquella por la que es llamada en otras. $Y$ esto que él mismo aparenta considerar como evidente a partir de las proposiciones generales sobre el alma, Aristóteles afirma de manera expresa que no es evidente en todas las partes del alma; en efecto, decir forma y perfección primera es expresarse equívocamente sobre el alma racional y sobre las otras partes del alma ${ }^{87}$.

Avempace, sin embargo ${ }^{88}$, parece querer decir en lo que se trasluce de su discurso que el intelecto material es la facultad imaginativa en cuanto que está preparada para que las intenciones que están en ella sean inteligidas en acto, y que no existe otra facultad sino ésta que sea sujeto para los inteligibles. Avempace parece querer decir esto intentando huir de las contradicciones que se le presentan a Alejandro, a saber, que el sujeto que recibe las formas inteligibles sea un cuerpo formado de elementos, o una facultad en un cuerpo; pues si así fuera, ocurriría o bien que el ser de las formas en el alma sea el ser de ellas fuera del alma, y de ese modo el alma no podría captar, o bien que el intelecto tenga un órgano corporal, si el sujeto de los inteligibles es una facultad en un cuerpo, como sucede en los sentidos.

$Y$ lo que es más absurdo en la interpretación de Alejandro es su afirmación de que las primeras preparaciones para los inteligibles y para las otras últimas perfecciones del alma son cosas producidas por composición y no facultades producidas por un motor extrínseco, como es la conocida opinión de Aristóteles y de todos los peripatéticos. Esa interpretación de las facultades perceptivas del alma, si es tal como la hemos entendido, es falsa. En efecto, de la sustancia de los elementos y de su naturaleza no puede surgir una facultad perceptiva distintiva porque si fuera posible que de su naturaleza y sin motor extrínseco se produjeran tales facultades, entonces sería posible que la última

87 La crítica de Averroes a Alejandro de Afrodisia se basa en que éste considera términos unívocos lo que son términos equívocos en Aristóteles. De ahí que no pueda aplicarse en el mismo sentido la definición aristotélica a todas las partes del alma. Lo que busca aquí Averroes es distinguir al intelecto material o alma intelectiva respecto de las otras partes del alma.

${ }_{88}$ A partir de aquí expone la posición de Avempace (Abubacher o Avempeche en el texto de Escoto), que refuta a continuación por parecerle insatisfactoria. 
perfección, que es el inteligible, fuera algo producido por la sustancia de esos elementos, como sucede con el color y el sabor. Esta opinión es semejante a la de quienes niegan las causas eficientes y no admiten sino las causas materiales ${ }^{89}$; y son aquellos que afirman el azar. Alejandro es de más excelencia como para opinar así; pero las dificultades a las que se enfrentaba respecto al intelecto material le forzaron a esta posición.

Volvamos, pues, a nuestro tema y digamos que quizá estas dificultades son las que indujeron a Avempace a afirmar esto respecto al intelecto material. Pero es evidente que resulta insostenible. En efecto, las intenciones imaginativas 90 mueven al intelecto, no son movidas. Se muestra, en efecto, que son aquello cuya relación con la facultad racional distintiva es como la relación del sensible con la facultad sensitiva, y no como la de la facultad sensitiva con el hábito que es la sensación. Y si recibiera los inteligibles, entonces una cosa se recibiría a sí misma, y el motor sería movido. Pero ya se ha manifestado que es imposible que el intelecto material tenga una forma en acto, dado que su sustancia y naturaleza consiste en recibir las formas en tanto que son formas.

Todo lo que puede decirse respecto a la naturaleza del intelecto material parece imposible, excepto lo que dijo Aristóteles, al cual también se le presentan no pocas dificultades; la primera de las cuales es que los inteligibles especulativos son eternos; la segunda es la más consistente de ellas, a saber, que la perfección última en el hombre está numerada según el número de los individuos humanos, mientras que la perfección primera es una en número para todos. La tercera dificultad es de Teofrasto y consiste en que es necesario mantener que este intelecto [material] no tiene ninguna forma y que él mismo es un ente; pues de no ser así, no habría recepción ni preparación. Pues la preparación y la recepción surgen de aquellas cosas que no se encuentran sino en un sujeto ${ }^{91}$. Y como es un ente y no tiene la naturaleza de una forma, queda [la posibilidad] de que tenga la naturaleza de la materia prima, lo cual es muy absurdo; la materia prima, en efecto, no es perceptiva ni distintiva. ¿Y cómo se puede decir de algo cuyo ser es tal que sea separado? ${ }^{92}$

89 La crítica va dirigida a los presocráticos, en la misma línea que la realizada por Aristóteles en Metafisica, 988b 20-29.

90 Intentiones ymaginate. GOMEZ NOGALES en un paso similar del Epitome, parágrafo 128, traduce el texto árabe por "formas imaginativas".

91 Sigo la variante non nisi del aparato crítico cuyo sentido es más coherente.

92 Quod est abstractum. 
Siendo todo esto así, me pareció conveniente escribir cuál es mi opinión sobre ello ${ }^{93}$. Y si esto que expongo no fuere completo, será [al menos] principio de algo perfecto. Pido, por tanto, a los hermanos que lean esta obra que pongan por escrito sus dudas, pues quizá mediante ello se encontrará la verdad, si es que yo no la encontré. Y si la he encontrado, como imagino, entonces se manifestará por medio de esas dificultades. La verdad, en efecto, como dice Aristóteles, concuerda consigo misma y se valida por sí sola ${ }^{94}$.

El problema de cómo los inteligibles especulativos ${ }^{95}$ son generables y corruptibles mientras que el que los produce y los recibe es eterno, y qué necesidad hay de introducir un intelecto agente y uno receptivo ${ }^{96}$ si no hay algo engendrado, esa cuestión no se plantearía si no hubiese aqui algo que es causa de que existan inteligibles especulativos engendrados. Pero ya que estos inteligibles están constituidos de dos cosas, una de ellas engendrada y otra inengendrada, lo que se ha dicho sobre esto es conforme al curso natural. Pues ya que concebir por el intelecto es, según afirma Aristóteles, como captar por la sensación ${ }^{97}$, y captar por la sensación se logra por medio de dos sujetos, uno de los cuales es el sujeto mediante el cual la sensación llega a ser verdadera (y es el sensible fuera del alma), y el otro es el sujeto mediante el cual la sensación es una forma existente (y es la perfección primera de la facultad sensitiva), es necesario también que los inteligibles en acto tengan dos sujetos, el primero de los cuales es el sujeto mediante el cual son verdaderos, es decir, las formas que son imágenes verdaderas, mientras que el segundo [sujeto] es aquél mediante el cual los inteligibles son un ente en el mundo, y éste es el intelecto material. Por consiguiente, no hay en esto ninguna diferencia entre la sensación y el intelecto, sino en que el sujeto de la sensación por el cual es verdadera existe fuera del alma, mientras que el sujeto del intelecto mediante el cual es verdadero se encuentra dentro del alma. $Y$ esto es lo que afirmó Aristóteles respecto a este intelecto [material], como se verá después.

93 Averroes expone a partir de ahora su propia posición, que intenta responder a las diversas aporías antes planteadas.

94 Esta confesión inicial del filósofo cordobés constituye una declaración de principios de su concepción dialéctica de la verdad.

95 Intellecta speculativa.

96 [intellectum] recipientem.

97 Sensus, que traduce el término griego áisthesis y que significa tanto "sentido" como "sensación" o "percepción sensible». 
Este sujeto del intelecto que, en cierto modo, es su motor es aquello que pensó Avempace que era el receptor, porque encontró al mismo a veces intelecto en potencia y a veces intelecto en acto, pues tal es la disposición del sujeto receptor, y por ello estimó procedente la conversión ${ }^{98}$.

Y esta analogía aparece más completa entre el sujeto que mueve a la vista y el sujeto que mueve al intelecto. Pues del mismo modo que el sujeto que mueve a la vista, es decir, el color, no la mueve sino cuando por la presencia de la luz se convierte en color en acto después haber estado en potencia, así las intenciones imaginativas ${ }^{99}$ no mueven al intelecto material sino cuando se convierten en inteligibles en acto después de haber estado en potencia. Y por esto fue necesario que Aristóteles introdujera un intelecto agente, como se verá después, que hace pasar estas intenciones de la potencia al acto. Del mismo modo, por tanto, que el color que está en potencia no es la perfección primera del color que es una entidad percibida, sino que el sujeto que se perfecciona por este color es la vista, así también el sujeto que se perfecciona por el inteligible no son las intenciones imaginativas que son inteligibles en potencia, sino el intelecto material que se perfecciona por los inteligibles, y cuya relación con ellos es como la existente entre la entidad del color y la facultad visual.

Y siendo esto así como decimos, sucede que los inteligibles que están en acto, es decir, los inteligibles especulativos, son generables y corruptibles por el sujeto gracias al cual son verdaderos, $y$ no por el sujeto gracias al cual son uno de los entes, es decir, el intelecto material ${ }^{100}$.

El segundo problema, a saber, cómo el intelecto material es uno en número en todos los individuos humanos, inengendrable e incorruptible, mientras

98 En contra de Avempace, Averroes defiende la necesidad de que el inteligible en acto tenga dos sujetos, uno que es el motor, la facultad imaginativa, y otro que es el receptor, el intelecto material.

99 Intentiones ymaginate, es decir, el contenido de la imaginación, el "fantasma". La huella aristotélica es evidente. Recuérdese que para el Estagirita la actividad de la phantasía o imaginación producía los phantásmata, es decir, las representaciones imaginativas.

100 Los inteligibles especulativos son, por tanto, eternos respecto al sujeto del que son la perfección última, es decir, el intelecto material, y generables y corruptibles respecto al sujeto del que son la perfección primera, es decir, las representaciones imaginativas. Como recuerda DE LIBERA, esta proposición fue condenada formalmente en el Syllabus del obispo Tempier ( $\mathrm{n}{ }^{\circ}$ 131): Quod intellectus speculativus simpliciter est aeternus et incorruptibilis; respectu vero huius hominis corrumpitur corruptis phantasmatibus in eo. 
que los inteligibles que existen en acto en él (y es el intelecto especulativo) se cuentan por el número de los individuos humanos y son generables y corruptibles por la generación y la corrupción de los individuos, este problema ciertamente es muy difícil y tiene una máxima ambigüedad ${ }^{101}$.

Si admitimos que este intelecto material se multiplica por el número de individuos humanos, tendrá que ser algo individual, o cuerpo o facultad en un cuerpo. Y si fuera algo individual, será una entidad inteligible en potencia. Pero la entidad inteligible en potencia es el sujeto que mueve al intelecto receptivo, y no el sujeto movido. Así pues, si se admite que el sujeto receptivo es algo individual, ocurrirá que una cosa se reciba a sí misma, como ya hemos dicho, lo cual es imposible.

Y si admitiéramos también que ella se recibe a sí misma, tendría que recibirse en cuanto distinta. Y así la facultad del intelecto sería igual que la facultad de la sensación, o no habría ninguna diferencia entre el ser de la forma fuera del alma y en el alma. La materia individual, en efecto, no recibe sino formas determinadas e individuales. Éste es uno [de los casos] que confirman que Aristóteles pensaba que este intelecto no es una entidad individual.

Y si afirmamos que no se multiplica por el número de los individuos, ocurrirá que su relación con todos los individuos existentes en su perfección últi$\mathrm{ma}$, en la generación ${ }^{102}$, será la misma, por lo cual es necesario si alguno de estos individuos adquiere algún inteligible, que sea adquirido por todos ellos. Pues si la conjunción ${ }^{103}$ de esos individuos [con el inteligible] se produce por la conjunción del intelecto material con ellos, del mismo modo que la conjunción del hombre con la entidad sensible se produce por la conjunción de la perfección primera del sentido con quien recibe la entidad sensible, (pues la conjunción del intelecto material con todos los hombres que existen en acto, en algún tiempo, debe ser la misma, en su perfección última; nada, en efecto, causa diferencia en la relación de conjunción entre ambos que están juntos), si

101 Consciente de su extrema dificultad, Averroes afronta este segundo problema que motivó una viva polémica en la Edad Media y cuya interpretación está lejos todavía de haber alcanzado la unanimidad entre los estudiosos.

102 Se sobreentiende «del inteligiblew.

103 Continuatio, término central en la noética de Averroes, traduce el árabe ittisâl, «unión» o "conjunción». Véase un paso similar en el Epltome, parágrafo 130, traducción de GOMEZ NOGALES; de interés también su nota 381. 
fuese así, digo, necesariamente cuando tú adquieras algún inteligible, yo también lo adquiriré, lo cual es imposible ${ }^{104}$.

Y da lo mismo si mantienes que la perfección última engendrada en cada individuo está sujeta a este intelecto, a saber, mediante la cual se une ${ }^{105}$ el intelecto material, y es como una forma separable de su sujeto con el cual se une; si hay algo que sea tal, o si mantienes que esa perfección es una facultad, ya de las facultades del alma, ya de las del cuerpo, se seguirá idéntico imposible.

Por tanto, hay que admitir que si hay algunos seres animados cuya perfección primera es una sustancia separada de sus sujetos, como se considera respecto de los cuerpos celestes, es imposible que se encuentre más de un individuo por especie. Pues si en ellas, es decir, en la misma especie respectiva se encontrara más de un individuo, por ejemplo, en un cuerpo movido por un mismo motor, entonces su ser sería inútil y superfluo al producirse su movimiento por la misma entidad numérica, como es inútil que un solo piloto tenga varias naves al mismo tiempo, e igualmente lo es el que un artesano tenga varios instrumentos de la misma especie ${ }^{106}$.

Éste es el sentido de lo que se dijo en el libro primero de Sobre el cielo y el mundo ${ }^{107}$, a saber, que si existiera otro mundo, existiría también otro cuerpo celeste; y que si existiera otro cuerpo celeste, habría también otro motor numéricamente [distinto] del motor de este cuerpo celeste; y que si fuera así, entonces el motor del cuerpo celeste sería material y numerado según el número de los cuerpos celestes, pues es imposible que un solo motor lo sea de dos cuerpos numéricamente distintos. Y por eso, el artesano no usa más de un instrumento, pues de él no proviene sino una única acción. Y se considera de modo universal que los absurdos ${ }^{108}$ que se le presentan a tal posición alcanzan también a ésta ${ }^{109}$,

104 Véase un paso similar en el Epitome, traducción S. GOMEZ NOGALES, parágrafo 118.

105 Copulatur.

106 En el contexto cosmológico en el que se sitúa la argumentación, Averroes supone que un cuerpo es movido por su motor respectivo, pues de otro modo habría motores ociosi, es decir, inútiles.

107 De Caelo et mundo. Aristóteles escribió un tratado físico titulado Peri ouranós. Posteriormente, se le atribuyó el tratado De Mundo, cuya autenticidad es rechazada por la crítica. En la tradición árabe aparecen unidos en una sola obra ambos títulos.

108 Impossibilia.

${ }_{109}$ Es decir, los absurdos lógicos o contradicciones que se le presentan a la tesis cosmológica anteriormente expuesta, alcanzan también a la similar tesis noética aquí debatida. 
a la afirmación de que el intelecto en hábito es uno en número. Muchos de esos [absurdos] ya los enumeró Avempace en su epístola titulada Sobre la unión del intelecto con el hombre ${ }^{110}$. Y siendo así, ¿cuál es el camino para resolver esta difícil cuestión?

Digamos, pues, que es evidente que el hombre no entiende en acto sino por la conjunción con él del inteligible en acto. Y también es evidente que la materia y la forma se unen entre sí de tal manera que el agregado de ellos es único, sobre todo el intelecto material y la intención inteligible en acto; en efecto, su compuesto no es una tercera cosa distinta de ellos, como ocurre con los otros compuestos de materia y forma. Así pues, es imposible que se dé la conjunción del inteligible con el hombre a no ser por la conjunción con él de una de estas dos partes, es decir, de la parte que en él es como materia, y de la parte que en él (o sea, en el inteligible) es como forma.

Y como ya se ha manifestado a partir de las precedentes dificultades ${ }^{111}$ que es imposible que el inteligible se una con cada uno de los hombres y se multiplique por su número por la parte de él que es como materia, es decir, el intelecto material, queda que la conjunción de los inteligibles con nosotros los hombres se produzca por la conjunción de la intención inteligible con nosotros (y son las intenciones imaginativas), o sea, de la parte de ellas que está en nosotros en cierto modo como forma.Y por esto, decir que un niño es inteligente en potencia puede entenderse de dos modos: el primero es que las formas imaginadas que están en él son inteligibles en potencia; y el segundo, que el intelecto material, a quien le es natural recibir al inteligible de aquella forma imaginada, es receptivo en potencia y unido con nosotros en potencia.

Se ha manifestado, pues, que la perfección primera del intelecto se distingue de las perfecciones primeras de las otras facultades del alma, y que el nombre de perfección ${ }^{112}$ se predica de ellas de modo equívoco, al contrario de lo que opinó Alejandro [de Afrodisia]. Y por esto dijo Aristóteles en la definición de alma como la perfección primera de un cuerpo natural orgánico, que todavía no es evidente si el cuerpo se perfecciona de igual modo por todas las facul-

110 Hay edición y traducción castellana de este texto por Miguel Asín Palacios en $A l$ Andalus, 1942, 7, pp. 1-47.

111 Dubitationes, que traduce el término aristotélico de aporíai.

112 Es decir, entelékheia. 
tades, o si existe alguna por la cual el cuerpo no se perfeccione, y si lo hace, será de otro modo.

La preparación de los inteligibles que está en la facultad imaginativa es semejante a las preparaciones que están en las otras facultades del alma, es decir, a las perfecciones primeras de las otras facultades del alma, en tanto que ambas preparaciones se generan por la generación del individuo y se corrompen por su corrupción, y universalmente se multiplican por el número [de los individuos].

Se diferencian en esto, que una es la preparación en el motor para que sea motor, es decir, la preparación que está en las intenciones imaginativas; la otra, sin embargo, es la preparación en el receptor, y es la que se da en las perfecciones primeras de las otras partes del alma.

Y por esta semejanza entre estas dos preparaciones creyó Avempace que no había ninguna preparación para hacer inteligible una cosa sino la preparación existente en las intenciones imaginativas. Pero estas dos preparaciones se distinguen como la tierra del cielo ${ }^{113}$; una, en efecto, es la preparación en el motor para que sea motor, y la otra es la preparación en lo movido para que sea movido y receptivo.

Por esto hay que admitir, como ya se nos mostró a partir del razonamiento de Aristóteles, que hay en el alma ${ }^{114}$ dos partes del intelecto, una de las cuales es receptora ${ }^{115}$, cuyo ser se expone aquí, y la otra es agente ${ }^{116}$, que hace que las intenciones que están en la facultad imaginativa muevan al intelecto material en acto después de haberlo movido en potencia, como se verá después a partir del discurso de Aristóteles; y que estas dos partes son inengendrables e incorruptibles; y que el agente es respecto al receptor como la forma respecto a la materia, como se explicará más adelante.

Y por esto pensó Temistio que nosotros somos el intelecto agente ${ }^{117}$, y que el intelecto especulativo no es otra cosa sino sólo la conjunción del intelecto

113 Differunt sicut terra a celo. Gráfica expresión de probable origen popular.

114 In anima. Es importante este matiz: no se distinguen realmente los intelectos agente y receptivo, sino que son dos partes que están «en el alma».

115 Recipiens.

116 Agens.

117 Temistio, In De Anima, III, 430a 23-24, edición de Verbeke, pp. 228-229. En polemica con Temistio, cuyas interpretaciones comparte con frecuencia, Averroes sintetiza su propia posición en este importante paso. 
agente con el intelecto material ${ }^{118}$. Pero no es* como él creyó, sino que hay que admitir que en el alma hay tres partes del intelecto ${ }^{119}$, una primera que es el intelecto receptivo ${ }^{120}$, una segunda que es el [intelecto] eficiente ${ }^{121}$, y una tercera que es el [intelecto] producido ${ }^{122}$. $\mathrm{Y}$ dos de estas tres [partes] son eternas, a saber, la agente y la receptiva; la tercera, sin embargo, es generable y corruptible en cierto modo, y en otro modo, eterna.

Puesto que hemos admitido a partir de este discurso que el intelecto material es único para todos los hombres, y también hemos admitido a partir de él que la especie humana es eterna ${ }^{123}$, como se ha expuesto en otras ocasiones, es necesario [concluir] que el intelecto material no está despojado de los principios naturales comunes a toda la especie humana, es decir, de las primeras proposiciones y de los conceptos ${ }^{124}$ singulares comunes a todos [los hombres]; estos inteligibles, en efecto, son únicos respecto al receptor y múltiples respecto a la intención recibida.

Así pues, según el modo mediante el cual [los inteligibles] son únicos, necesariamente son eternos, al no separarse del sujeto recibido, es decir, del motor,

118 Intellectus speculativus nichil est aliud nisi continuatio intellectus agentis cum intellectu materiali tantum.

119 Innovadora posición de Averroes sobre este punto. Adviértase que vuelve a señalar aquí que estas tres partes del intelecto in anima sunt, "están en el alma».

120 Intellectus recipiens.

121 Efficiens.

122 Factum.

123 Aquí se condensan las dos acusaciones centrales tanto de la Escolástica como de la filosofía moderna contra Averroes y los averroístas: el monopsiquismo y la eternidad del mundo. El obispo Tempier, siempre celoso de la ortodoxia, condenó ambas. Aristóteles defendió en su Fisica la eternidad del mundo, y en De Anima, II, 415b 3-7 afirmó que el hombre es mortal y sólo la especie era eterna. Algacel, por su parte, desde la ortodoxia de los teólogos islámicos, criticó también acremente la tesis de la eternidad del mundo mantenida por los peripatéticos árabes. El pensamiento del filosofo cordobés sobre esta cuestión ha sido magníficamente reconstruido por Idoia MAIZA OzCOIDI, La concepción de la filosofia en Averroes. Andilisis critico del Tahâfut al-tahâfut, Madrid, Trotta, 2001, pp. 185-254. La posición de Averroes puede resumirse así: "La doctrina de la creación ex nibilo es filosbficamente inaceptable y absolutamente incompatible con las ensefianzas de Aristóteles sobre el origen del ser. En cuanto a la creencia en un mundo temporal o intemporal, eso es una cuestión de fe. El creyente puede aferrarse a la idea del inicio temporal del mundo, si así lo desea. Pero el que, además de creyente, sea hombre de ciencia, sabe que es mucho mas plausible la idea de un mundo eterno, sin principio ni fin, y, por consiguiente, cree en ellan, ibid., p. 252, cursiva de la autora.

124 Formationibus [per intellectum], que equivaldría aquí a noémata. Recuérdese que Escoto traduce noeîn como formare per intellectum. 
que es la intención de las formas imaginativas, y no haber alli obstáculo por parte del receptor ${ }^{125}$. Pues la generación y la corrupción no se produce en ellos sino por la multiplicidad que les afecta, y no por el modo mediante el cual son únicos. Y por esto, cuando respecto de un individuo se corrompe alguno de los primeros inteligibles por la corrupción del sujeto mediante el cual está unido con nosotros y es verdadero, ese inteligible necesariamente es incorruptible en sentido absoluto ${ }^{126}$, pero corruptible respecto a cada uno de los individuos. Es de este modo como podemos afirmar que el intelecto especulativo es uno en todos [los hombres] ${ }^{127}$.

Si se consideran estos inteligibles en tanto que son entes en sentido absoluto, $y$ no respecto a un individuo, en verdad se dice que son eternos, y no son pensados unas veces sí y otras veces no, sino siempre. Su ser es como un punto intermedio entre el ser fugaz y el ser permanente ${ }^{128}$. En efecto, según el aumento y la disminución que les produce la perfección última, son generables y corruptibles, mientras que en tanto que son únicos en número, son eternos.

Esto sucedería si no se afirmara que la disposición en la perfección última del hombre es como la disposición en los inteligibles comunes a todos, a saber, que el ser del mundo no está privado de tal ser individual. Que esto sea imposible, no es evidente; al contrario, el que dice esto puede tener una razón suficiente y tranquilizadora para el alma. Pues al ser la sabiduría en cierto modo algo propio de los hombres, así como las clases de artesanía existen en modos propios de los hombres, se considera imposible que toda la tierra habitada abandone la filosofia ${ }^{129}$, del mismo modo que hay que pensar que es imposible que abandone las artes naturales. En efecto, si alguna parte de aquélla [la tierra habitada] careciera de ellas, es decir, de las artes, como, por ejemplo, el cuarto septentrional de la tierra, no carecerán de ellas los otros cuartos, pues

125 Es decir, del intelecto material, que es eterno.

126 Simpliciter.

127 Siger de Brabante repite esta tesis, que él consideraba aristotélica: Intellectus speculativus in hoc homine est corruptibilis, est tamen secundum se et simpliciter aeternus, ut dicit Averroes. Et ita videtur sensisse Aristóteles: In III De anima, edición de Carlos BAZAN, p. 29.

128 En un paso paralelo del Epttome, traducción de S. GOMEZ NOGALES, parágrafo 121, se puede leer:m...en los inteligibles una parte es evanescente y otra parte es permanente. Y por eso es tan confusa la especulación de los investigadores sobre ellosn (cursiva mía).

129 Existimatur quod impossibile est ut tota habitatio fugiat a Philosohia. Averroes muestra aquí una confianza absoluta en la permanencia de la filosofla como actividad radicalmente humana. 
ya se ha explicado que la población humana es posible tanto en la parte meridional como septentrional.

La filosofia, pues, quizá exista en todo tiempo en la mayor parte del sujeto, como el hombre existe por el hombre, y el caballo por el caballo. El intelecto especulativo es, según este modo, inengendrable e incorruptible.

$\mathrm{Y}$ universalmente es así respecto del intelecto agente que crea los inteligibles, como respecto del intelecto receptivo que distingue. En efecto, del mismo modo que el intelecto agente nunca cesa de engendrar y de crear en sentido absoluto ${ }^{130}$, aunque quede excluido de la generación algún sujeto, así sucede también con el intelecto que distingue.

Y a esto alude Aristóteles en el [libro] primero de este tratado, cuando dijo: "Pensar ${ }^{131}$ y especular ${ }^{132}$ son cosas distintas, de tal manera que en el interior alguna otra cosa se corrompe, pero él mismo [el intelecto] en sí no sufre corrupción ${ }^{133}$ alguna» ${ }^{134}$. Por alguna otra cosa entiende las formas imaginadas humanas. Y por pensar entiende la recepción que hay siempre en el intelecto material, la cual pretendía problematizar ${ }^{135}$ en este libro y en el otro cuando dijo: "Y no recordamos porque éste no es pasivo ${ }^{136}$; pero el intelecto pasivo es corruptible ${ }^{137}, \mathrm{y}$ sin éste nada piensa» ${ }^{138}$.

Entiende [Aristóteles] por intelecto pasivo la facultad imaginativa, como se explicará después. Y de modo universal se consideró esta intención ale-

130 Intellectus agens nunquam quiescit a generando et creando simpliciter. El intelecto agente está, por tanto, en permanente acción y es esencialmente creativo.

131 Formare per intellectum, que traduce el verbo griego noeîn.

132 Considerare, que traduce el verbo theorein.

133 Ipsum autem in se nullam habet corruptionem, que vierte el conciso texto aristotélico autd apathes estin.

134 De Anima, I, 408b 24-25.

135 Dubitare: recuérdese su conexión con aporfa. El texto que sigue es, sin duda, uno de los más aporéticos de todo el tratado. He estudiado a fondo este paso y su controvertida traducción en Atomos, hombres y dioses. Estudios de filosofla griega, Madrid, Tecnos, 1988, pp. 131-132.

136 Quia iste est non passivus. Esta traducción desfigura el texto griego. Lo que Aristóteles escribió es hoti touto apathés, es decir, "porque éste es impasible». En esta referencia polémica a la anámnesis platónica, Aristóteles afirma que no hay recuerdo tras la muerte porque el intelecto creativo o agente es impasible y el receptivo o pasivo es corruptible. La memoria y el recuerdo quedan asi indisolublemente asociados a la vida del ser humano concreto.

137 Intellectus autem passivus est corruptibilis. En el texto aristotélico se lee: ho dè pathetikós nous phthartós. La traducción latina es correcta.

138 De Anima, III, 430a 23-25. 
jada ${ }^{139}$ [de la verdad], a saber, que el alma es inmortal, o sea, el intelecto especulativo.

De aquí que Platón dijera que los universales son ingenerables e incorruptibles, y que existen fuera de la mente ${ }^{140}$. Y es un discurso verdadero en este sentido, pero falso en el sentido literal de sus palabras (y es este sentido el que intentó refutar Aristóteles en la Metafisica). De modo universal esta concepción del alma es parcialmente verdadera en las proposiciones probables que conceden al alma ser una y otra cosa, es decir, mortal e inmortal; en efecto, es imposible que las [proposiciones] probables sean totalmente falsas. Esto lo trataron los antiguos, y en su representación están de acuerdo todas las leyes [religiosas].

El tercer problema (cómo el intelecto material es un ente, y no es ninguna de las formas materiales, ni tampoco la materia prima) se resuelve así. Hay que pensar que éste es un cuarto género de ser. En efecto, del mismo modo que el ser sensible se divide en forma y materia, así es necesario que el ser inteligible se divida en algo semejante a estas dos, o sea, en algo semejante a la forma y en algo semejante a la materia. $Y$ esto es necesario [que se produzca] en toda inteligencia separada ${ }^{141}$ que piense una cosa distinta [de sí], pues si no, no habría una multiplicidad en las formas separadas. Ya se ha afirmado en la Metafisica ${ }^{142}$ que no hay ninguna forma que esté liberada absolutamente de la potencia, sino la primera forma ${ }^{143}$, la cual nada piensa fuera de sí, sino cuya existencia ${ }^{144}$ es su quididad; en las demás formas, sin embargo, la quididad y la existencia se diferencian de algún modo. Y si no hubiera este género de entes que hemos conocido en la ciencia del alma, no podríamos concebir la multi-

139 A remotis. Literalmente indica lejanía física. En este contexto gnoseológico, la referencia debe ser a la verdad. No obstante, el sentido es oscuro. En cuanto al problema de fondo, dado que el intelecto especulativo está ligado a las formas imaginativas, será generable y corruptible, aunque las formas de los inteligibles sean eternas. Así lo interpretan, por ejemplo, Salvador GOMEZ NOGALES ("El destino del hombre a la luz de la Noética de Averroes", en L'homme et son destin, Lovaina-París, Éditions Nauwelaerts, 1960, pp. 295-298) e Idoia MAIZA, La concepción de la filosofia en Averroes, cit., pp. 354-358. Alain DE LIBERA, lo traduce en el mismo sentido. Augusto ILIUMINATI, sin embargo, lo interpreta en sentido contrario, o sea, aceptando la inmortalidad del intelecto especulativo.

140 Extra mentem.

141 Intelligentia abstracta.

142 Literalmente, Prima Pbilosophia.

143 Dios.

144 Essentia. Escoto recoge un uso antiguo de este término como sinónimo de «esse» y de "exsistentia". 
plicidad en las cosas separadas, del mismo modo que si no conociéramos ahora la naturaleza del intelecto, no podríamos entender que las potencias motrices separadas deben ser intelectos ${ }^{145}$.

Esto se le ocultó a muchos modernos, de tal suerte que negaron lo que dice Aristóteles en el libro XI de la Metafisica, que es necesario que las formas separadas que mueven los cuerpos celestes sean igual en número a los cuerpos celestes. Por eso, es necesario saber del alma para saber metafísica ${ }^{146}$. Y este intelecto receptivo es necesario que entienda ${ }^{147}$ al intelecto que está en acto. En efecto, al haber entendido las formas materiales, es más digno que entienda las formas inmateriales; $y$ lo que entiende de las formas separadas, por ejemplo, del intelecto agente, no le impide entender las formas materiales.

La proposición que afirma que el que recibe no debe tener en acto nada de lo recibido, no se dice absolutamente sino de modo condicionado, o sea, que no es necesario que el que recibe no sea nada en absoluto en acto, sino que no sea en acto algo de aquello recibido, como hemos dicho antes. Es más, debes saber que la relación del intelecto agente con este intelecto [material] es la relación de la luz con lo diáfano, y que la relación de las formas materiales con él es como la del color con lo diáfano. En efecto, lo mismo que la luz es la perfección de lo diáfano, así el intelecto agente es la perfección del [intelecto] material. Y lo mismo que lo diáfano no es movido por el color ni lo recibe sino cuando luce, así este intelecto no recibe los inteligibles que están aquí sino cuando es perfeccionado por aquel intelecto e iluminado por él. Y así como la luz hace que el color en potencia lo sea en acto, de modo que pueda mover lo diáfano, así también el intelecto agente hace que las intenciones inteligibles en potencia lo sean en acto para que el intelecto material las reciba. De este modo, pues, hay que concebir al intelecto material y al [intelecto] agente.

145 Se da aquí un salto del plano noético al cosmológico. Gracias al progreso alcanzado en su concepción del intelecto, Averroes propone una nueva explicación del movimiento de los cuerpos celestes. Estos no estarían compuestos de materia y forma, y no necesitarían, por tanto, de almas o formas corporales que los muevan, sino que son movidos directamente por los intelectos separados.

146 Et ideo scire de anima necessarium est in sciendo Primam Philosophiam. Averroes vuelve a subrayar la importancia epistemológica de la Psicología, que experimentó con él un avance considerable a partir de las tesis aristotélicas, y cuya autonomía como ciencia se esforzó en fundar. Si unas líneas antes veíamos las aplicaciones de la noética a la cosmología, ahora se advierte su fecundidad especulativa, su riqueza filosofica desde el punto de vista de la metafísica.

147 Intelligat. 
Y cuando el intelecto material se ha unido en cuanto que es perfeccionado gracias al intelecto agente, entonces nosotros estamos unidos con el intelecto agente; y esta disposición se llama adquisición e intelecto adquirido ${ }^{148}$, como se verá después. Esta concepción de la esencia del intelecto material resuelve todos los problemas que se presentaban por el hecho de haber afirmado que el intelecto es uno y múltiple ${ }^{149}$. Puesto que si el inteligible en ti y en mí fuera uno en todos los aspectos, ocurrirá que, cuando yo conozca un inteligible, tú también lo conozcas, y otros muchos absurdos. Y si afirmamos que es múltiple, ocurrirá que el inteligible en mí y en ti será uno específicamente y dos individualmente; y de ese modo el inteligible tendría un inteligible, y así al infinito. Sería imposible también que el discípulo aprendiera del maestro, a no ser que la ciencia que está en el maestro sea una potencia generadora y creadora ${ }^{150}$ de la ciencia que está en el discípulo, a la manera como este fuego engendra otro fuego semejante a él específicamente, lo cual es imposible. Que lo conocido sea lo mismo en el maestro y en el discípulo es lo que hizo que Platón creyera que el conocimiento era una reminiscencia ${ }^{151}$. Pero si afirmamos que el objeto inteligible que está en mí y en ti es múltiple en el sujeto en cuanto es verdadero, o sea, las formas de la imaginación, y es uno en el sujeto por el cual es un intelecto existente ${ }^{152}$ (es decir, el intelecto material), se resuelven perfectamente estas dificultades.

La manera en que Avempace pensó resolver los problemas que se presentan acerca de esto, que el intelecto sea uno o múltiple, quiero decir, la que presentó en su epístola titulada Sobre la unión del intelecto con el hombre, no es una manera conveniente para resolver este problema. En efecto, el intelecto que

148 Adeptio et intellectus adeptus.

149 Quod intellectus est unus et multa. Con esta última formulación de la naturaleza del intelecto material, Averroes se muestra confiado en haber logrado superar las aporías que se planteaban.

150 Virtus generans et creans.

151 Quod disciplina esset rememoratio. Disciplina significa aquí "conocimiento", "ciencia». Para Platón, en efecto, la epistéme era una anámnesis: conocer es recordar.

152 Est intellectus ens. La expresión resulta oscura. El pensamiento de Averroes, sin embargo, es claro. La ciencia es una en un sentido, y por eso tiene validez universal; y es múltiple en otro, es decir, en cuanto que son muchos los individuos que la poseen. Se comprende ahora la deformación que sufrió la posición de Averroes sobre el intelecto material en la Escolástica cristiana, a pesar de haberse difundido esta traducción latina del Gran Comentario. Como escribe DE LIBERA a propósito de la tesis «averroísta» n. ${ }^{\circ} 148$ condenada por Tempier, esa tesis "es todo menos averroísta". 
demostró en esa epístola que es uno, cuando trabajaba en resolver tal problema, es distinto del intelecto que demuestra también allí que es múltiple, pues el intelecto que él demostró que era uno es el intelecto agente en cuanto que necesariamente es forma del intelecto especulativo; sin embargo, el intelecto que demostró que era múltiple es el mismo intelecto especulativo. Por otra parte, este nombre, a saber, intelecto, es usado de modo equivoco tanto respecto al especulativo como al agente.

Por eso, si lo que se entiende por este nombre intelecto en dos discursos opuestos, es decir, en uno que concluye que el intelecto es múltiple y en otro que concluye que el intelecto es uno, es un significado no equívoco, entonces lo que presentó [Avempace] después sobre esto, a saber, que el intelecto agente es uno y el especulativo múltiple, no resuelve este problema. Y si lo que se entiende por este nombre intelecto en esos dos discursos opuestos tiene un significado equivoco, entonces la dificultad ${ }^{153}$ será sofística y no dialéctica ${ }^{154}$. Por eso, hay que creer que los problemas que presentó aquel hombre en su epistola no se resuelven sino de este modo, si aquellas dificultades no son sofísticas sino dialécticas ${ }^{155}$. Y de este modo se resuelve el problema que se debatía sobre el intelecto material, si es extrínseco o está unido [a nosotros]. Una vez que se ha explicado esto, volvamos a la exposición del discurso de Aristóteles.

Texto 36. Y asi como la cosa separada [de la materia] es pensada cuando [el intelecto] piensa estas cosas (pues aquello que está en acto universalmente es el intelecto que está en acto), nuestra reflexión al final será si puede pensar alguna de las cosas separadas, estando él mismo separado de la extensión ${ }^{156}$, o no.

153 Dubitatio, que, como ya hemos visto, vierte el término griego aporía. DE LIBERA lo traduce por «duda".

154 Disputativa. El sentido es éste: la superación de las aporlas mediante la argumentación filosófica conducirá a la verdad. Si no se trata de sofismas basados en equívocos, hay que ir al problema mismo sirviéndose de la dialéctica como método. Creo ver en este enfoque de Averroes un eco del libro B de la Metafisica. Me he ocupado de este tema en mi trabajo "La concepción de la historia de la filosofía en Aristóteles".

155 A juzgar por los escritos de Avempace de que disponemos, y a pesar de su oscuro estilo literario, agravado por el hecho de que la mayoría de sus obras están incompletas, la crítica de Averroes parece excesiva. La noética de avempaciana es innovadora y coherente al mismo tiempo.

${ }^{156}$ Magnitudo, que traduce el término mégethos. 
Et sicut res abstracta intelligitur cum intelligit istas res (illud enim quod est in actu universaliter est intellectus qui est in actu), et cogitatio nostra in postremo erit utrum possit intelligere aliquam rerum abstractarum, cum hoc quod ipse est abstractus a magnitudine, aut non: 431b 16-19.

Y del mismo modo que la cosa que abstrae el intelecto se hace intelecto cuando la abstrae y la piensa, al ser necesario universalmente en el intelecto que aquello que es inteligido en acto sea intelecto en acto, debemos examinar y reflexionar en última instancia si este intelecto que está en nosotros pueda pensar algo que es en sí intelecto y separado de la materia, así como piensa aquello que lo hace inteligible en acto después de ser inteligible en potencia.Y dijo: "estando separado de la extensión". Así figura en este texto.Y si es verdadero, debe entenderse así: es decir, debemos en última instancia pensar si es posible que el intelecto que está en nosotros conciba las cosas separadas de la materia en cuanto están separadas de la extensión, y no por comparación con otra cosa. Pero en otro manuscrito figura así, de diversa manera: "y al final examinaremos si el intelecto, estando en un cuerpo, y no separado de él, pueda comprender algo de aquellas cosas que están separadas de los cuerpos, o no". Esta cuestión es distinta de la anterior. En efecto, esta cuestión es propia del que admite que el intelecto que está en potencia piensa las formas separadas de la materia absolutamente, y no en cuanto que está unido a nosotros; de acuerdo con esta interpretación habrá que indagar si puede concebir las formas en cuanto que está unido a nosotros, y no si puede concebir las formas de modo absoluto. Esta interpretación es mantenida por Temistio en su libro Sobre el alma; y la primera cuestión, que pretendía tratar al final, quedó relegada.

Es necesario, pues, examinar si es posible que el intelecto material piense las cosas separadas o no; y si las piensa, si es posible que las piense en cuanto que está unido a nosotros, o no. Y por eso, es posible que en el manuscrito del cual transcribimos este texto figurara esta partícula no ${ }^{157}$, de modo que así deba leerse: "y nuestra reflexión ${ }^{158}$ será al final si pueda pensar alguna de las cosas separadas, aunque él mismo no esté separado de la extensión", o sea, en

157 Como en otras ocasiones, Averroes se permite corregir una traducción cuando la hermenéutica del texto así lo exige. Véase el artículo de A. BADAWI, uAverroès face au texte qu'il commente", en Multiple Averroès, J. Jolivet, ed., París, Les Belles Lettres, 1978, pp. 60-89, donde figuran algunos ejemplos similares.

158 Cogitatio nostra. 
cuanto que toca la extensión y está unido a nosotros, de modo que nosotros pensemos aquel inteligible que él mismo piensa. Esta indagación ${ }^{159}$ que intenta es muy difícil y ambigua, y conviene que la llevemos a cabo en cuanto nos sea posible.

Digamos, pues: quien mantiene que el intelecto material es generable y corruptible, no puede encontrar, según me parece, un modo natural por el cual podamos unirnos con los inteligibles separados. El intelecto, en efecto, debe ser inteligible en todos los modos ${ }^{160}$, y principalmente en las cosas liberadas de la materia. Así pues, si fuese posible que la sustancia generable y corruptible pensara las formas separadas y se convirtiera en lo mismo que ellas, entonces sería posible que la naturaleza de lo posible se hiciera necesaria, como dijo al-Fârâbî en [el Comentario a la Etica] nicomáquea; y ésta es una deducción necesaria según los principios de los sabios ${ }^{161}$.

A no ser que alguien diga que la interpretación que pretende Alejandro [de Afrodisia], a saber, sobre la existencia del intelecto adquirido ${ }^{162}$, no es la formación producida de nuevo en el intelecto material, la cual no existía antes, sino que él mismo se une con nosotros en una unión tal que para nosotros es la forma por la cual pensamos los otros entes, como se concluye del razonamiento de Alejandro. Aunque de ello no sea evidente el modo según el cual esta conjunción ${ }^{163}$ es posible; porque si planteamos que esta conjunción es producida después de no existir, como es necesario, ocurrirá que en el momento en el cual se dé la existencia, habrá una cambio ${ }^{164}$ en el receptor, en lo recibido, o en ambos. Y dado que es imposible que lo haya en lo recibido, queda que lo sea en el receptor; $y$ como en el receptor se da un cambio que antes no existía, necesariamente habrá allí una recepción recién producida ${ }^{165}$ y una

\section{Perscrutatio.}

160 Intellectus enim debet esse intellectum omnibus modis. Tesis de inspiración aristotélica. Como he escrito en otro lugar, para Aristóteles "el nous es inteligible como lo son sus objetos. De ser éstos inmateriales (y, por tanto, inteligibles en acto), se identifica con ellos y al conocerlos se conoce a sí mismo. Si son objetos materiales (o inteligibles en potencia), no hay en ellos sino inteligibilidad potencial, pues el nous conoce a sus objetos sin materia; pero él mismo es en sf inteligiblen: Atomos, hombres y dioses. Estudios de filosofia griega, cit., p. 129.

161 Et hoc necessarium est secundum fundamenta sapientum.

162 De existentia intellectus adepti.

163 Continuatio.

164 Transmutatio, que vierte el término aristotélico metabolé.

165 Facta ex novo. 
sustancia receptora recién producida, que antes no existía. De plantear, pues, una nueva recepción, se repetirá el problema anterior. $Y$ si no planteamos una recepción específica nuestra ${ }^{166}$, no habrá diferencia entre la conjunción de él con nosotros y la conjunción de él con todos los entes, ni entre la conjunción de él con nosotros en éste y en otro momento, a no ser que defendamos que la conjunción de él con nosotros se produce de un modo distinto al de la recepción. ¿YY cuál es ese modo?

Por el silencio respecto de este modo en Alejandro, vemos que él mismo duda sobre esto. Pues a veces dice que aquello que piensa el inteligible separado ${ }^{167}$ no es el intelecto material, ni el intelecto habitual ${ }^{168}$ : tales son sus palabras en el libro Sobre el alma. El intelecto que piensa esto [el inteligible separado] es el que no se corrompe, no el intelecto material sujeto; en efecto, el intelecto material se corrompe por la corrupción del alma, ya que es una facultad de ella, y al corromperse este intelecto, se corromperá su facultad y su perfección. Además, después de declarar que es necesario que el intelecto que está en nosotros y piensa las formas separadas sea inengendrable e incorruptible, afirmó que este intelecto es el intelecto adquirido según la opinión de Aristóteles, y dijo:

"Así pues, el intelecto que no se corrompe es este intelecto que está separado en nosotros, al que Aristóteles llama adquirido porque está en nosotros del exterior ${ }^{169}$, y no es una facultad que esté en el alma, ni un hábito mediante el cual pensamos las otras cosas y también este intelecto ${ }^{170}$ \%.

Si, pues, entendía por intelecto adquirido, mediante el cual pensamos las inteligencias separadas, la inteligencia agente ${ }^{171}$, entonces queda por explicar el modo de conjunción de este intelecto con nosotros. Y si entendía un intelecto separado distinto del [intelecto] agente, como se manifiesta en la opinión de alFârâbî en su Epistola sobre el Intelecto, y en tanto que lo podemos comprender

166 Receptionem propriam nobis.

167 Intellectum abstractum.

168 Intellectus qui est in habitu.

169 Ab extrinseco. En uno de sus últimos tratados escribió Aristóteles: «sólo el intelecto viene de fuera [thýrathen] y sólo él es divinon, De Generatione Animalium, 736 b28. Sin embargo, él no utilizó nunca la expresión «intelecto adquirido".

170 De anima, ed. I. Bruns, pp. 90-91.

171 Intelligentiam agentem. 
a partir de la explicación expuesta, entonces la cuestión acerca del modo de conjunción de este intelecto con nosotros es también la misma que la del modo de conjunción del intelecto agente [con nosotros] para quien crea que el [intelecto] agente se identifica con el [intelecto] adquirido. Y esto es más que evidente del discurso de Alejandro. Esto, pues, dijo en su libro Sobre el alma acerca del modo de conjunción del intelecto que está en acto con nosotros.

Sin embargo, lo que dijo en un tratado que hizo Sobre el Intelecto según la opinión de Aristoteles parece contradecir lo que dijo en el libro Sobre el alma. Estas son sus palabras:

"Y el intelecto que está en potencia, cuando está completo y acrecentado, entonces piensa al agente; porque del mismo modo que la potencia de andar que el hombre tiene al nacer llega a realizarse después de un tiempo, cuando se perfecciona aquello mediante lo cual se anda, asi el intelecto, cuando es perfecto, piensa aquello que es por su naturaleza inteligible, y hace a los sensibles inteligibles ${ }^{172}$, porque es agenten ${ }^{173}$.

Es evidente que esta explicación contradice la que expone en el libro Sobre el alma, a saber, que el intelecto que está en potencia no piensa al que está en acto.

Pero si uno considera todas las explicaciones de este hombre ${ }^{174} \mathrm{y}$ las agrupa, verá que él opina que, cuando el intelecto que está en potencia sea perfecto, entonces se unirá con nosotros la inteligencia agente, por la cual pensamos las cosas separadas y por la cual hacemos que las cosas sensibles sean inteligibles en acto, en tanto que él mismo ${ }^{175}$ se convierte en forma en nosotros. Y como que entiende por esta explicación que el intelecto que está en potencia, cuando sea perfecto y esté completo, entonces se unirá con él este intelecto [agente] y se hará forma en él, y entonces pensaremos por medio de él las otras cosas; no de tal modo que el intelecto material lo piense y por ese pensar se produzca la conjunción con este intelecto, sino que la conjunción de este intelecto con nosotros es la causa de que [el intelecto material] lo piense y de que pensemos por él las otras cosas separadas.

\footnotetext{
172 Et faciet sensata esse intellecta.

173 De intellectu, ed. cit. de I. Bruns, pp. 110-111.

174 Alejandro de Afrodisia.

175 O sea, el intelecto agente.
} 
Y puedes saber que tal es la opinión de este hombre por lo que dijo en aquel tratado:

«así pues, aquel inteligible por su naturaleza, que es el intelecto en acto, al ser causa del intelecto material abstrayendo y formando cada una de las formas materiales, $y$ ascendiendo hasta esa forma, se dice que es adquirido agente ${ }^{176}$; y no es parte del alma ni facultad del alma, sino que se produce en nosotros desde fuera ${ }^{177}$, cuando pensamos por medio de el ${ }^{178, \%}$.

Es evidente, pues, que entiende por esta explicación que, cuando el intelecto que está en acto sea causa según la forma ${ }^{179}$ del intelecto material en una acción propia de él (y esto será por la ascensión del intelecto material hasta esa forma), entonces se llamará intelecto adquirido, ya que en aquella disposición pensaremos ${ }^{180}$ gracias a él, pues es forma para nosotros; ya que entonces será una última forma para nosotros.

La base de esta opinión es que el intelecto agente es primeramente causa eficiente ${ }^{181}$ del intelecto material y del intelecto habitual, y por eso no se une con nosotros desde el principio y pensamos por él las cosas separadas. Una vez que el intelecto material sea perfecto, entonces el [intelecto] agente se hará forma del material, y se unirá con nosotros, y pensaremos por él las otras cosas separadas; pero no que el intelecto habitual piense este intelecto, pues el intelecto habitual es generable y corruptible, mientras que aquél es inengendrable e incorruptible ${ }^{182}$.

Pero a esta [opinión] se le presenta el problema ya aludido, y es que lo que ahora ${ }^{183}$ es forma para el intelecto habitual, cuando antes no lo era, proviene de cierta disposición de reciente producción en el intelecto habitual y que es la causa por la que aquel intelecto [adquirido agente] es forma para el intelecto habitual cuando antes no lo era. Y si esta disposición no es una recepción del intelecto habitual en el intelecto agente, ¿qué cosa es? Porque si es una recepción ${ }^{184}$, le suce-

\footnotetext{
176 Adeptus agens.

177 Ab extrinseco.

178 De intellectu, ed. cit., p. 111.

179 Es decir, causa formal.

180 Erimus intelligentes.

181 Causa agens.

182 Non generabilis neque corruptibilis.

183 Modo.

184 Receptio.
} 
derá que lo engendrado reciba a lo eterno y se le asemeje, y así lo engendrado se convertirá en eterno, lo cual es imposible.

Y por esto vemos que al-Fârâbî al final, habiendo creído que la opinión de Alejandro sobre la generación del intelecto material era verdadera, le fue necesario según esta opinión creer que la inteligencia agente no es sino la causa eficiente sólo para nosotros; y esto lo afirmó explícitamente en su [Comentario a la Ética] Nicomáquea ${ }^{185}$. Y está en contra de su propia opinión en la Epistola sobre el Intelecto; alli, en efecto, dijo que es posible que el intelecto material piense las cosas separadas; y ésta es la opinión de Avempace. Tales son los problemas que se le presentan a los que afirman que el intelecto material es engendrado, y que el fin [del hombre] es la conjunción con las cosas separadas ${ }^{186}$.

$\mathrm{Y}$ vemos también que le siguen problemas no menores que éstos a los que defienden que él mismo [el intelecto material] es una facultad separada. Porque si en la naturaleza de este intelecto material está el que piense las cosas separadas, es necesario que siempre, en el futuro y en el pasado, las piense. Parece, pues, que se sigue de esta posición que desde el momento en que el intelecto material se une con nosotros, desde ese momento el intelecto agente se une también con nosotros. Pero esto es impensable y contrario a lo que afirman todos.

Mas ese problema puede resolverse por lo que afirmamos antes, es decir, que el intelecto material no se une con nosotros por sí y desde el principio ${ }^{187}$, sino que se une con nosotros por su unión ${ }^{188}$ con las formas de la imaginación ${ }^{189}$. Y siendo así, es posible decir que el modo según el cual se une con nosotros el intelecto material es distinto del modo según el cual él mismo se une con el intelecto agente. Si es distinto, entonces no se da ninguna conjunción [del intelecto agente con nosotros]; y si es el mismo pero primero está en

185 Para Averroes, sin embargo, el intelecto agente es causa eficiente y también causa formal de nuestro conocimiento. Al final del presente capítulo volverá a criticar a al-Fârâbî por esta razón.

186 Continuari cum abstractis. Averroes va indicando las aporías que sucesivamente se le presentan a quienes, desde su perspectiva, mantienen una concepción inadecuada del intelecto material.

187 Per se et primo.

188 Per suam copulationem.

189 En este comienzo de su respuesta a las aporías planteadas a Alejandro de Afrodisia, alFârâbî y Avempace, Averroes parte de un replanteamiento del problema de la conjunción con el intelecto agente. 
una disposición y después en otra, ¿ qué tipo de disposición es? Y si planteamos que el intelecto material separado no tiene naturaleza [capaz] de pensar las cosas separadas, entonces la duda ${ }^{190}$ será mayor. Todos éstos son, pues, los problemas que les surgen a los que mantienen que la perfección humana consiste en pensar las cosas separadas.

Conviene que nosotros ofrezcamos también explicaciones por las cuales se cree concluir que tenemos una naturaleza [capaz] de pensar finalmente las cosas separadas; estas explicaciones, en efecto, son muy opuestas a aquellas; y quizá mediante esto podamos ver la verdad ${ }^{191}$. Ahora bien, la causa de esta duda y del esfuerzo [que supone] se debe a que no encontramos explicación alguna de Aristóteles sobre este tema, a pesar de que Aristóteles prometió tratarlo ${ }^{192}$.

Digamos, pues, que Avempace investigó mucho sobre esta cuestión y se esforzó en poner de manifiesto que esta unión es posible en la epístola que tituló De la unión del intelecto con el hombre; y en el Libro sobre el alma y en otros muchos libros [donde] parece que esta cuestión no se alejó de su reflexión, ni siquiera en el tiempo del guiño de un ojo. Y ya comentamos aquella epístola según nuestra capacidad. Este problema, en efecto, es muy difícil y cuando tal fue el resultado de Avempace en esta cuestión, ¡cuánto más de otro hombre! El razonamiento de Avempace sobre esto es más sólido que el de los demás, aunque se le presentan problemas de los que ya hemos hecho mención ${ }^{193}$. Conviene que aludamos aquí a los métodos ${ }^{194}$ de este hombre, pero antes a lo que dijeron los comentaristas sobre este punto.

\section{Ambiguitas.}

191 Et forte per hoc poterimus videre veritatem. El filósofo cordobés se muestra confiado, pero cauteloso al mismo tiempo, en poder alcanzar la verdad sobre el tema.

192 Averroes es consciente de tener que avanzar por sí solo sin ayuda de Aristóteles. Su innovación venía obligada por las aporías presentes en las explicaciones de los comentadores griegos y árabes de Aristóteles. Pero la falta de textos aristotélicos sobre ello está en el origen del esfuerzo teórico a realizar. Es evidente, en contra de los tópicos, que Averroes no se limitó a comentar, sino que se atrevió a ir más allá de Aristóteles como filósofo por derecho propio.

193 Este elogio a Avempace merece destacarse por su importancia. En efecto, Averroes reconoce en el filósofo zaragozano su amplia investigación sobre el tema, su esfuerzo personal, el interés permanente en él, y, sobre todo, el haber superado a todos los demás comentadores de Aristóteles en finura especulativa. En un gesto de generosidad intelectual por su parte, incluso se considera empequenecido ante Avempace, mostrándose dudoso de poder superar los escollos que provocaba el tema de la conjunción con el intelecto agente. Los dos grandes filósofos de alAndalus fueron también los que mejor especularon sobre la noética.

194 Vias. 
Temistio se apoyó en el tópico del mayor. Dice, en efecto, que al tener el intelecto material la potencia para abstraer las formas de la materia y de pensarlas, tanto más tiene la [capacidad] innata de pensar aquello que desde el principio está desprovisto de materia. Y de esta explicación resultará que el intelecto material es corruptible o incorruptible, es decir, separable o no separable. Según la opinión de los que dicen que el intelecto material es una facultad en el cuerpo, y que es engendrado, esta explicación será suficiente en cierto modo, pero no concluyente. No se sigue, en efecto, que lo que es visible en sí sea lo más visible para nosotros, vg. el color y la luz del sol; pues el color tiene menos indicación de visibilidad que el sol, dado que el color no es visible sino por medio del sol, aunque no podamos mirar al sol como al color; y esto le sucede a la vista por la mezcla de materia.

Pero si afirmamos que el intelecto no está mezclado con la materia, entonces ciertamente aquella explicación será verdadera, es decir, que aquello que es más inteligible, se percibe más; ya que lo que percibe lo menos perfecto (de entre las cosas perceptibles que no están mezcladas con la materia), es necesario que perciba lo más perfecto, y no al contrario. Mas si esto es necesario por su propia naturaleza y sustancia ${ }^{195}$, le surgirá el problema ya mencionado, que es: ¿cómo no se une [el intelecto agente] con nosotros desde el principio, o sea, tan pronto como el intelecto material se une con nosotros? Y si afirmamos que se une con nosotros al final, y no desde el principio, debemos dar una explicación ${ }^{196}$.

Ante tal problema, Alejandro, por su parte, se fundamenta en esto, a saber: todo ente engendrado cuando llegue a su fin en la generación y a la perfección última, entonces llegará al término y fin en su acción, si perteneciera a los entes activos, o en su pasión, si perteneciera a los entes pasivos, o en ambas, si perteneciera a los dos; por ejemplo, no llega al fin en su acción que es andar sino cuando llega al fin en la generación. Y como el intelecto habitual es uno de los entes generables, es necesario que cuando llegue a [su] fin en la generación, llegue al fin en su acción. Puesto que su acción consiste en crear inteligibles y pensarlos, es necesario, cuando llegue a la perfección última, que tenga de modo perfecto estas dos acciones. Y la perfección al crear inteligibles es hacer que todos los inteligibles en potencia sean inteligibles en acto; y el término al

195 Se sobreentiende "del intelecto material".

196 Reddere causam. 
pensar es pensar todas las cosas separadas y no separadas. Es necesario, por tanto, que cuando el intelecto habitual llegue a término en su generación, tenga estas dos acciones.

De esta interpretación surgen problemas no pequeños. No es evidente por sí, en efecto, que el término de su acción que es pensar sea pensar las cosas separadas, a no ser que esta palabra imaginar ${ }^{197}$ se predique de ellas [las cosas separadas] y de las cosas materiales unívocamente ${ }^{198}$, como se predica la palabra andar ${ }^{199}$ de lo más imperfecto y de lo más perfecto.

$\mathrm{Y}$ además, ¿cómo se atribuye la acción propia del intelecto agente, que es crear inteligibles, a un intelecto generable y corruptible, o sea, al [intelecto] habitual? A no ser que se mantenga que el intelecto habitual es el intelecto agente compuesto con el intelecto material, como afirma Temistio, o se mantenga que la forma última para nosotros por la cual abstraemos los inteligibles y los pensamos está compuesta del intelecto habitual y del intelecto agente, como mantienen Alejandro y Avempace, y como nosotros también estimamos que se trasluce del texto de Aristóteles.

Incluso si admitiéramos que fuera así, no se derivaría del término de su acción que es crear los inteligibles sino el término de la acción al pensarlos, y no al pensar las cosas separadas, puesto que el pensarlas es imposible que se atribuya a la generación, o al llegar a ser por algún ente engendrado (por ejemplo, por el intelecto habitual), salvo de modo accidental; y si no [fuera así], entonces lo generable se convertiría en eterno, como dijimos.

Además, se le presenta una grave problema ${ }^{200}$ a la explicación que afirma que la forma por la cual extraemos los inteligibles es el intelecto habitual compuesto con el intelecto agente. Lo eterno, en efecto, no necesita en su acción de lo generable y corruptible. ¿Cómo, pues, se compone lo eterno con lo corruptible, de tal modo que de ellos se produzca una sola acción? Pero después hablaremos de esto. Parece, por tanto, que esta posición es como el principio y fundamento de lo que queremos decir acerca de la posibilidad de la conjunción con las cosas separadas según Aristóteles, es decir, la tesis según la cual la forma última para

$\begin{array}{ll}197 & \text { Ymaginari. } \\ 198 & \text { Univoce. } \\ 199 & \text { Ambulare. } \\ 200 & \text { Magna questio. }\end{array}$


nosotros por la cual extraemos los inteligibles y los producimos a nuestra voluntad está compuesta del intelecto agente y del intelecto habitual. Esto es lo que opinamos acerca de la explicación de los comentadores peripatéticos respecto a que este fin es posible, es decir, el pensar al final las cosas separadas ${ }^{201}$.

Avempace, por su parte, habló mucho de esto, y especialmente en la epístola que tituló De la unión del intelecto con el hombre. Y aquello sobre lo que se basó en esta cuestión es esto: en primer lugar, declaró que los inteligibles especulativos son productos; después, afirmó que todo producto tiene una quididad; después, que de todo lo que tiene quididad el intelecto es capaz por naturaleza de extraerla; de lo cual se concluye que el intelecto es capaz por naturaleza de extraer las formas de los inteligibles y sus quididades. $Y$ en esto coincide con al-Fârâbî en el libro Sobre el intelecto y el inteligible, y de aquí lo extrajo Avempace, concluyendo esto, que el intelecto es capaz por naturaleza de extraer las formas de los inteligibles y sus quididades.

Y siguió en esto dos métodos, uno de los cuales se encuentra en la epistola, y el segundo en el Libro sobre el alma, y están próximos entre sí. En el Libro sobre el alma ańadió a esto que la multiplicidad ${ }^{202}$ no se produce en los inteligibles de las cosas a no ser por la multiplicación ${ }^{203}$ de las formas espirituales por las cuales se mantienen en cada individuo, y por esto el inteligible del caballo es distinto en mí de ese inteligible en ti. De lo cual se deduce por conversión de los opuestos que todo inteligible que no tenga forma espiritual en la que sustentarse, es el mismo en ti y en mI. Después, añadió a esto que la quididad del inteligible y su forma no tienen forma espiritual individual en la cual sustentarse, pues la quididad del inteligible no es la quididad de un individuo singular, ni espiritual, ni corporal: se ha declarado, en efecto, que el inteligible no es individual. De lo cual se deduce que le es natural al intelecto el pensar la quididad de un inteligible cuyo inteligible es único ${ }^{204}$ para todos los hombres: $y$ lo que es tal es una sustancia separada.

201 Tal como habla prometido, Averroes sintetiza en estos parágrafos las diversas soluciones propuestas por los comentadores griegos al problema de hacer compatible lo eterno y lo generable, o sea, de pensar las formas separadas en un intelecto corruptible. A juzgar por sus palabras finales, su conclusión no es optimista: subsisten las aporías de fondo.

202 Multitudo.

203 Per multiplicationem.

204 Sigo la lectura del manuscrito G, intellectum est unum; CRAWFORD, por su parte, lee intellectus est unus. 
Pero en el Libro sobre el alma planteó en primer lugar que si no se nos concede que la quididad del inteligible en cuanto que es inteligible no tiene quididad, y que no es simple sino compuesta (como sucede en todas las quididades producidas), y se dice que la quididad de este inteligible en cuanto que inteligible tiene también una quididad, es decir, el inteligible de esta quididad, entonces este intelecto será también capaz por naturaleza de volver [a ella] y de extraer aquella quididad.

Y si no se nos concede que esta quididad es simple y que el ente en ella se identifica con el inteligible, ocurrirá en ella lo que ocurrió en la primera [quididad], que tenga también una quididad producida. Entonces es necesario o que se proceda al infinito, o que el intelecto se detenga allí. Pero como es imposible el proceso al infinito (porque haría que infinitas quididades e intelectos fueran diversos específicamente, a saber, en cuanto que algunos de ellos están más liberados de materia que otros), es necesario que el intelecto se detenga. $Y$ cuando se detiene, entonces o llegará a una quididad que no tiene quididad, o a algo que tiene quididad pero que el intelecto no tiene capacidad natural para extraerla, o a algo que ni tiene quididad ni es una quididad. Pero es imposible encontrar una quididad que el intelecto no sea capaz por naturaleza de extraer de una quididad, porque entonces aquel intelecto no se diría intelecto sino de modo equívoco (al haberse establecido que el intelecto es capaz por naturaleza de abstraer la quididad en aquello que es quididad). Y también es imposible que el intelecto llegue a algo que ni tiene quididad ni es una quididad; pues lo que no es una quididad ni tiene quididad, es la privación absoluta. Queda, por tanto, una tercera división, a saber, que el intelecto llegue a una quididad que no tenga quididad; $y$ lo que es tal, es la forma separada. Confirmó [Avempace] esto por lo que suele decir Aristóteles en tales demostraciones, a saber, que cuando es menester quitar el infinito, mejor es quitarlo al comienzo.

La conclusión de esta demostración será, pues, la misma que la conclusión de la demostración anterior. Porque si no añadiera esto, podría alguien decir que hay muchos intelectos intermedios entre el intelecto habitual y el intelecto agente: o bien uno, como sostiene al-Fârâbî en su tratado Sobre el intelecto $y$ el inteligible, al que llamó alll adquirido, o bien más de uno. Y se considera que al-Fârâbî admitió esto [último] en su Libro sobre la generación y la corrupción, donde dice: «¿cómo se llevan a término ${ }^{205}$ estos intelectos intermedios?»,

205 Conficiuntur: prefiero asi la lectura del manuscrito A, en lugar de la elegida por CRAWFORD, consumuntur. 
es decir, [aquellos] cuyo ser pusimos entre el intelecto especulativo y el intelecto agente. Éstas, pues, son las vías más seguras por las cuales caminó este hombre en esta cuestión.

Ahora bien, digamos nosotros: si este nombre quididad, se afirma de modo unívoco de las quididades de las cosas materiales y de las quididades de los inteligibles separados, entonces la proposición que afirma que el intelecto es capaz por naturaleza de abstraer las quididades en cuanto que son quididades, será verdadera; $y$ [ocurrirá] de manera semejante si fuera unívoco el afirmar que los inteligibles son compuestos y que los individuos son compuestos; pero si fuera equívoco, entonces la demostración no será verdadera. Sin embargo, es muy difícil [saber] cómo es la demostración ${ }^{206}$; en efecto, es evidente por si que este nombre quididad no se predica de estas cosas ni de modo puramente univoco, ni de modo puramente equívoco. Pero si se predica de muchos modos ${ }^{207}$, lo cual es intermedio, necesita de explicación.

Pero si concedemos que esto [la quididad] se predica de modo unívoco, se presentará el problema anterior; y es de qué modo lo corruptible piensa lo que no es corruptible, según la opinión de los que afirman que el intelecto material es corruptible (tal es la opinión de Avempace); o, según la opinión de los que afirman que el intelecto material es inengendrable e incorruptible, cómo lo que es capaz por naturaleza de pensar siempre aquellas cosas, tanto en el futuro como en el pasado, piensa ${ }^{208}$ con una intelección nueva. $Y$ si mantenemos que pensar las cosas separadas está en la sustancia y en la naturaleza del intelecto material, ¿̨por qué esta intelección no se mueve en paralelo ${ }^{209}$ con nuestras intelecciones de las [formas] materiales, de tal suerte que este pensar sea parte de las ciencias especulativas, y sea uno de los problemas en la ciencia especulativa?

Avempace parece dudar en este punto. Dijo, en efecto, en la Epistola del adiós que la posibilidad es de dos modos: natural y divina; es decir, que la intelección de este intelecto es de posibilidad divina, no de posibilidad natural. Sin embargo, en la Epistola de la unión afirmo: "y cuando el filósofo haya subido en esa ${ }^{210}$ ascensión, contemplando el inteligible en cuanto inteligible, enton-

206 Acepto la lectura del manuscrito A, demonstratio, no seguida por CRAWFORD.

207 Multipliciter.

208 Intelligit intellectione nova.

209 Non currit cursu.

210 Acepto la lectura del manuscrito D, illa, como propone A. DE LIBERA, en lugar de alia. 
ces pensará la sustancia separada». Y resulta evidente de esto que concebir al inteligible ${ }^{211}$ es, según él, parte de las ciencias especulativas, o sea, la Ciencia Natural ${ }^{212}$; esto se [nos] mostró de él en esa investigación.

Y si es así, todos los hombres somos ignorantes de esta ciencia ${ }^{213}$ [por estas tres razones]: o porque todavía no conocemos las proposiciones que nos llevan a esta ciencia (como se dice de muchas artes que parecen ser posibles pero que se deben a causas desconocidas, por ejemplo, la Alquimia); o porque este pensar se adquiere mediante el ejercicio y el uso de las cosas naturales, pero todavía no poseemos el ejercicio y el uso en un grado tal que podamos conseguir esta intelección; o será de modo natural por decaimiento de nuestra naturaleza.

$\mathrm{Si}$, pues, esto sucede por un decaimiento en la naturaleza, entonces nosotros y todos los que tienen la capacidad natural de adquirir esta ciencia nos llamamos hombres de modo equívoco. Y si esto sucede por ignorancia de las proposiciones que conducen a esta ciencia, entonces la ciencia especulativa no es perfecta todavía; y Avempace dijo que quizá esto era desatinado ${ }^{214}$, pero no imposible. Y si esto sucede por costumbre, entonces la explicación será parecida a la que afirma que la causa de esto radica en la ignorancia de las proposiciones que conducen a esta ciencia. Todo lo dicho parece desatinado aunque no imposible ${ }^{215}$. ¿Y cómo poder escapar a los problemas ya mencionados?

Estos son, pues, todos los problemas que suscita esta cuestión, y son tan difíciles como ves. Conviene que digamos lo que se nos manifestó sobre esto ${ }^{216}$. Digamos, pues: puesto que el intelecto que existe en nosotros ${ }^{217}$ tiene dos actividades en cuanto que nos es atribuído, una de las cuales es del

211 Intelligere intellectum, es decir, llevar a cabo la intelección del inteligible, pensarlo.

212 Scientia Naturalis. Para Aristóteles, como es sabido, las ciencias especulativas son la Física o Ciencia de la Naturaleza, es decir, la Scientia Naturalis, las Matemáticas, y la Filosofía Primera o, como se llamaría después, la Metafisica.

213 Se sobreentiende, por el párrafo anterior, "del inteligible separado".

214 Remotum [a ratione].

215 Averroes ha examinado a fondo en los parágrafos anteriores la posición de Avempace sobre el tema, contraponiendo a veces diversos textos suyos. La conclusión no le parece satisfactoria, pues las dificultades suscitadas no acaban de desaparecer.

216 Después de haber reflejado las interpretaciones de los comentadores griegos y de Avempace, Averroes comienza a formular su propia concepción, intentando superar las aporías planteadas.

217 Intellectus existens in nobis. 
género de la afección ${ }^{218}$ (y es pensar), y otra del género de la acción ${ }^{219}$ (y consiste en extraer las formas y despojarlas de la materia, lo que no es otra cosa sino hacerlas inteligibles en acto después de que estaban en potencia), es evidente que está en nuestra voluntad, una vez que poseamos un intelecto habitual, pensar cualquier inteligible que queramos y extraer cualquier forma que deseemos.

Y esta acción, a saber, crear los inteligibles y producirlos, es anterior en nosotros a la acción de pensar, como afirma Alejandro. Por esto dice que es más apropiado describir al inteligible por esta acción, y no por la afección, pues en la afección participa algo de las facultades animales ${ }^{220}$ (aunque esto es según la opinión de los que afirman que la afección no se predica en ellos de modo equívoco).

Por esta acción, o sea, la de extraer cualquier inteligible que queramos y de producirlo en acto después de que estaba en potencia, opinó Temistio que el intelecto habitual se compone del intelecto material y del agente. $\mathrm{Y}$ esto mismo hizo que Alejandro creyera que el intelecto que está en nosotros está compuesto o cuasi compuesto ${ }^{221}$ del intelecto agente y del habitual, al opinar que la sustancia del [intelecto] habitual debe ser distinta de la sustancia del intelecto agente.

Establecidos estos dos principios ${ }^{222}$, a saber, que el intelecto que está en nosotros tiene estas dos actividades, captar los inteligibles y producirlos, pues los inteligibles se generan en nosotros de dos modos: o naturalmente ${ }^{223}$ (y son las primeras proposiciones, que ignoramos cuándo aparecieron, de dónde y cómo) o voluntariamente ${ }^{224}$ (y son los inteligibles adquiridos a partir de las primeras proposiciones); y ya se manifestó que es necesario que los inteligibles poseídos naturalmente por nosotros procedan de algo que es en sí un intelecto liberado de la materia ${ }^{225}$ (y es el intelecto agente); manifestado esto, es necesario que los inteligibles posé́dos por nosotros desde las primeras proposicio-

\footnotetext{
218 Passionis.

219 Actionis.

220 Communicet ei aliud ex virtutibus animalibus.

221 Est compositus aut quasi compositus.

222 Fundamenta.

223 Naturaliter.

224 Voluntarie.

225 Intellectus liberatus a materia.
} 
nes sean algo producido, mezcla ${ }^{226}$ a partir de las proposiciones conocidas y del intelecto agente. En efecto, no podemos decir que las proposiciones no penetren en el ser de los inteligibles adquiridos ${ }^{227}$, como tampoco podemos decir que ellas sean los únicos agentes (ya se manifestó, en efecto, que el agente es uno y eterno), como pretendían algunos de los antiguos que opinaron que a ellas se refería Aristóteles con el término intelecto agente.

Y siendo así, es necesario que el intelecto especulativo sea algo engendrado por el intelecto agente y por las primeras proposiciones. $Y$ sucede que este modo de los inteligibles es voluntario, al contrario que los inteligibles primeros [que son] naturales. En toda acción producida por la agregación de dos cosas diversas es necesario que una de las dos sea cuasi materia e instrumento, y que otra sea cuasi forma o agente ${ }^{228}$. Así pues, el intelecto que está en nosotros se compone del intelecto habitual y del intelecto agente, o bien de tal manera que las proposiciones son cuasi materia y el intelecto agente es cuasi forma, o bien de tal manera que las proposiciones son cuasi instrumento y el intelecto agente es cuasi [causa] eficiente; la disposición, en efecto, es semejante.

Pero si establecemos que las proposiciones son cuasi instrumento, sucederá que la acción eterna ${ }^{229}$ provenga de dos cosas, una de las cuales es eterna y la otra no lo es (o se establece que el instrumento es eterno, y entonces los inteligibles especulativos serán eternos). Y más aún sucederá esto si establecemos que aquellas proposiciones son cuasi materia; es, en efecto, imposible que algo generable y corruptible sea la materia de lo eterno. ¿Cómo, pues, podremos escapar de este problema?

Digamos, pues, que si esto que afirmamos, que es necesario que las proposiciones sean respecto al intelecto agente cuasi materia o cuasi instrumento ( $\mathrm{si}$ penetran en el ser de los inteligibles especulativos), no fue una explicación de la necesaria conclusión según la cual la materia es materia y el instrumento es instrumento, sino en cuanto que es necesario que exista aquí una proporción y disposición entre el intelecto agente y las proposiciones, las cuales se asemejan a la materia y al instrumento en cierto modo, y no porque sea verdadera

226 Congregatum.

227 Non habent introitum in esse intellectorum acquisitorum.

228 El latín es muy expresivo y el castellano se ajusta perfectamente: alterum sit quasi materia et instrumentum, et aliud sit quasi forma aut agens.

229 Se sobreentiende «del intelecto agente». 
materia o verdadero instrumento. Nos parece entonces que podemos conocer el modo según el cual el intelecto habitual es cuasi materia y sujeto del [intelecto] agente. $Y$ una vez que hayamos establecido este modo, quizá podamos fácilmente conocer el modo según el cual se une con los inteligibles separados.

Digamos, pues: la explicación del que afirma que si las conclusiones son adquiridas por nosotros del intelecto agente y de las proposiciones, es necesario que las proposiciones sean respecto al intelecto agente como una verdadera materia y un verdadero instrumento, esa explicación, digo, no es necesaria; sino que sólo es necesario que allí haya una relación ${ }^{230}$, según la cual el intelecto habitual se asemeje a la materia y el intelecto agente se asemeje a la forma. ¿Cuál es esta relación, y de dónde le viene al intelecto agente el tener esta relación con el intelecto habitual, [cuando] uno es eterno y el otro es generable y corruptible? En efecto, todos estos [comentadores] admiten que esta relación existe; y casi les obliga esto, que los inteligibles especulativos existen en nosotros a partir de estos dos intelectos, a saber, el habitual y el intelecto agente.

Pero Alejandro y todos los que opinan que el intelecto material es generable y corruptible no pueden dar razón de tal relación. A los que mantienen que el intelecto operante ${ }^{231}$ es el intelecto habitual, les llevará [a admitir] que los inteligibles especulativos son eternos, y otros muchos imposibles que se derivan de esta posición.

Para nosotros, sin embargo, habiendo mantenido que el intelecto material es eterno y que los inteligibles especulativos son generables y corruptibles en el modo que dijimos, y que el intelecto material piensa ambas, es decir, las formas materiales y las formas separadas, resulta evidente que, según este modo, el sujeto de los inteligibles especulativos y del intelecto agente es uno y el mismo, a saber, [el intelecto] material. Y se asemeja a esto lo diáfano, que recibe al mismo tiempo el color y la luz; y la luz es lo que produce el color.

Una vez que nos ha sido verificada esta conjunción que existe entre el intelecto agente y el intelecto material, podremos descubrir el modo según el cual decimos que el intelecto agente es semejante a la forma y que el intelecto habitual es semejante a la materia. En efecto, en todas las cosas cuyo sujeto es uno, y de las cuales una es más perfecta que la otra, es necesario que la relación de

231 Intellectus operans. 
la más perfecta a la más imperfecta sea como la relación de la forma a la materia. Y según esta interpretación, decimos que la analogía de la perfección primera de la facultad imaginativa con la perfección primera del sentido general ${ }^{232}$ es como la analogía de la forma con la materia.

Así pues, ya hemos encontrado el modo según el cual es posible que este intelecto se una con nosotros al final, y la causa por la cual ${ }^{233}$ no se une con nosotros al principio. Porque, admitido esto, sucederá necesariamente que el intelecto que está en nosotros en acto esté compuesto de los inteligibles especulativos y del intelecto agente, de tal manera que el intelecto agente sea cuasi forma de los inteligibles especulativos, y los inteligibles especulativos sean cuasi materia. Y gracias a este modo podremos engendrar inteligibles cuando queramos. Puesto que aquello por lo cual algo realiza su acción propia es la forma, y nosotros realizamos mediante el intelecto agente nuestra acción propia, es necesario que el intelecto agente sea una forma en nosotros ${ }^{234}$.

Y no existe ningún modo según el cual se genere la forma en nosotros sino éste. Puesto que cuando se unen los inteligibles especulativos con nosotros mediante las formas imaginativas ${ }^{235}$, y el intelecto agente se une con los inteligibles especulativos (pues el que los capta es el mismo, o sea, el intelecto material), es necesario que el intelecto agente se una con nosotros mediante la conjunción de los inteligibles especulativos.

Es evidente que, cuando todos los inteligibles especulativos existan en nosotros en potencia, él mismo estará unido a nosotros en potencia. $Y$ cuando todos los inteligibles especulativos existan en nosotros en acto, él estará entonces unido a nosotros en acto. Y cuando algunos estén en potencia y otros en acto, él estará entonces unido en parte sí y en parte no. Se dice entonces que nos movemos hacia la conjunción.

$Y$ es evidente que cuando este movimiento haya concluido, al instante este intelecto se unirá a nosotros en todos los modos. Y entonces resulta evidente

232 Communis sensus, es decir, el koiné bisthesis aristotélico, al que tradicionalmente se le denomina usentido común». En Atomos, bombres y dioses, cit., p. 120, he razonado por qué se debe traducir usentido general".

233 Sigo el manuscrito C: causa propter quam.

234 Sit forma in nobis. Es una afirmación explícita, y completamente novedosa en el ámbito medieval, del intelecto agente como intrínseco al hombre, en contra de la tradición filosófica árabe.

235 Per formas ymaginabiles. 
que en ese estado la relación de él ${ }^{236}$ respecto a nosotros es como la relación del intelecto habitual respecto a nosotros. $Y$ siendo así, es necesario que el hombre piense todos los entes mediante un intelecto suyo propio ${ }^{237}$, y que realice en todos los entes una acción suya propia, de la misma manera que, cuando está unido con las formas imaginativas, piensa mediante el intelecto habitual todos los entes con una intelección propia.

Así pues, según este modo, el hombre, como dice Temistio, se asemeja a Dios en esto, que es en cierto modo todos los entes, y los conoce en cierto modo; pues los entes no son otra cosa sino su ciencia, y la causa de los entes no es otra cosa sino su ciencia ${ }^{238}$. ¡Cuán admirable es este orden, y cuán extrańo este modo de ser!

De este modo se verificará la opinión de Alejandro cuando dice que pensar las cosas separadas se hará por la conjunción de este intelecto con nosotros; no que el pensar se dé en nosotros después de no existir, lo cual es la causa de la conjunción del intelecto agente con nosotros, como pensaba Avempace, sino que la causa de la intelección es la conjunción, y no al contrario.

Y por esto desaparece el problema de cómo lo eterno ${ }^{239}$ piensa con una intelección nueva. De aquí resulta evidente por qué no nos unimos con este intelecto al principio sino al final. Ya que, en tanto que sea forma en potencia para nosotros, estará unido con nosotros en potencia, y en tanto que esté unido con nosotros en potencia, es imposible que pensemos algo mediante él. Pero cuando se convierta en forma en acto para nosotros (y esto será en la conjunción de él [con nosotros] en acto), entonces pensaremos por él todo lo que pensamos, y realizaremos por él la acción que le es propia.

236 Se sobreentiende «del intelecto agente".

237 Per intellectum sibi proprium.

238 En línea con el racionalismo aristotélico, continuado por Temistio (a quien el filósofo andalusí sigue en casi todas las grandes cuestiones), Averroes defiende aquí la divinización del hombre por el intelecto, polémica tesis que fecundaría también a la Escolástica cristiana. Esta posición concuerda con la expuesta en sus tratados teológicos y en el Taháfut, donde se muestra claramente su racionalismo religioso: me he ocupado puntualmente del tema en mi artículo "Ibn Rusd, renovador de la filosofía en el mundo medieval", en $A$ l encuentro de Averroes, edición de Andrés MARTINEz LORCA, Madrid, Trotta, 1993, pp. 47-49. Sobre la actitud de Averroes ante la religión puede verse un análisis profundo y matizado en Idoia MAIZA OzCOIDI, La concepción de la filosofia en Averroes, cit., pp. 66-88.

239 Antiquum. 
De aquí resulta patente que su intelección no pertenece a las ciencias especulativas, sino que es el proceso de desarrollo natural del aprendizaje de las ciencias especulativas. Y por ello no es absurdo ${ }^{240}$ que los hombres se ayuden en esta tarea, lo mismo que se ayudan en las ciencias especulativas. Pero es necesario que ese proceso sea descubierto por las ciencias especulativas, y no por otras. En efecto, es imposible que los inteligibles falsos impliquen la conjunción, pues no son un proceso natural, sino algo que no se buscaba, como un sexto dedo y un monstruo en la creación.

También es evidente que, si afirmamos que el intelecto material es generable y corruptible, no encontraremos entonces una vía mediante la cual el intelecto agente se una con el intelecto habitual por una unión propia ${ }^{241}$, a saber, por una unión semejante a la conjunción ${ }^{242}$ de las formas con la materias.

$\mathrm{Y}$ de no plantear esta conjunción, no habrá diferencia entre compararlo [a este intelecto] con el hombre y con todos los entes, a no ser por la diferencia de su acción en ellos. Y según este modo, la relación de él con el hombre no será sino la relación del agente con el hombre, y no la relación de la forma, y se presentaría el problema que planteó al-Fârâbî en [su Comentario a la Ética] nicomáquea. Pues la confianza en la posibilidad de la conjunción del intelecto con nosotros descansa en la afirmación de que su relación con el hombre es la relación de la forma y del agente, y no sólo la relación del agente.

Esto se nos manifestó sobre esta cuestión. Y si después se nos manifestara más, lo escribiremos. 